\title{
The Status of Radiation Damage Experiments
}

\author{
D. M. Strachan \\ R. D. Scheele \\ J. P. Icenhower \\ A. E. Kozelisky \\ R. L. Sell \\ V. L. Legore \\ H. T. Schaef \\ M. J. O'Hara \\ C. F. Brown \\ W. C. Buchmiller
}

November 2001

Prepared for the U.S. Department of Energy under Contract DE-AC06-76RL01830 


\section{The Status of Radiation Damage Experiments}

D. M. Strachan

R. D. Scheele

J. P. Icenhower

A. E. Kozelisky

R. L. Sell

V. L. Legore

H. T. Schaef

M. J. O'Hara

C. F. Brown

W. C. Buchmiller

November 2001

Prepared for the U.S. Department of Energy

under Contract DE-AC06-76RL01830

Pacific Northwest National Laboratory

Richland, Washington 99352 



\section{Summary}

This is a status report on the progress of the radiation damage experiments that are being performed at the Pacific Northwest National Laboratory in support of the Plutonium Immobilization Program (PIP) to dispose plutonium that is surplus to the defense needs of the US. This report covers the progress of radiation damage from the decay of ${ }^{238} \mathrm{Pu}$ to the titanate phases that comprise the PIP ceramic. With the exception of brannerite, all the phases are represented in the specimens we are testing and characterizing. The phases appear to damage faster than anticipated from the information in the literature. Pyrochlore appears to become metamict 2 to 3 times faster. Zirconolite is more resistant, but this depends on what impurities are present.

Radiation damage results in swelling of the specimens. After 650 days, the trend in the data suggest that swelling will continue as the damage process appears to be incomplete (it has not yet "saturated" or reached a steady-state condition). The decrease in density from swelling is between $8 \%$ and $15 \%$, based on measurements of the pyrochlore baseline and a zirconolite-rich ceramic. The linear expansion of the specimen dimensions is between $2 \%$ and $5 \%$.

The dissolution rate appears to be between 500 - 1000 times greater for a ${ }^{238} \mathrm{Pu}$-bearing pyrochlore baseline sample than for the corresponding ${ }^{239} \mathrm{Pu}$ specimen. Although we believe that this increase in rate is due to radiation damage, we cannot be absolutely certain because we did not manage to obtain SPFT data on these specimens before damage started to accumulate. It is possible that the increased rate is due to some effect related to the higher dose rate and radiation field near the ${ }^{238} \mathrm{Pu}$ specimens that we don't understand. 



\section{Acronyms}

$\begin{array}{ll}\text { DIW } & \text { deionized water } \\ \text { DOE } & \text { U.S. Department of Energy } \\ \text { GEA } & \text { gamma energy analysis } \\ \text { ICP } & \text { inductively coupled plasma } \\ \text { MS } & \text { mass spectroscopy } \\ \text { OES } & \text { optical emission spectroscopy } \\ \text { RW } & \text { Office of Civilian Radioactive Waste Management } \\ \text { SPFT } & \text { single-pass flow-through (test) } \\ \text { THAM } & \text { tris hydroxymethyl aminomethane } \\ \text { XRD } & \text { X-ray diffraction }\end{array}$





\section{Contents}

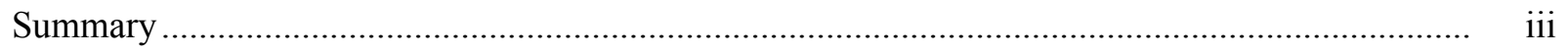

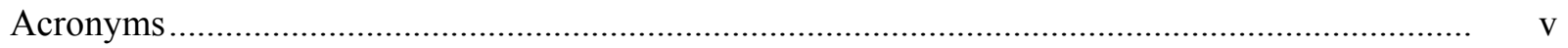

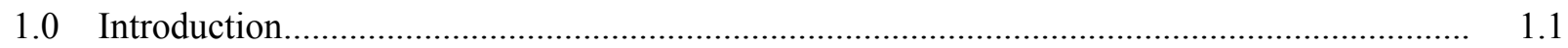

$2.0 \quad$ Experimental Methods ...................................................................................... 2.1

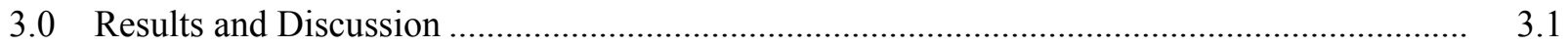

3.1 Damage Cumulative Radiation........................................................................ 3.1

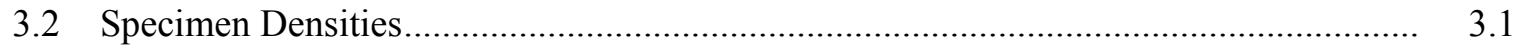

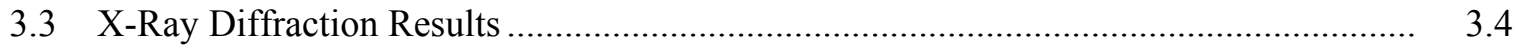

3.4 Dissolution Results - Static Tests....................................................................... 3.9

3.5 Dissolution Results - Dynamic Tests .............................................................. $\quad 3.10$

3.5.1 Experiments with ${ }^{239} \mathrm{Pu}$-Bearing Ceramic................................................ 3.10

3.6 Experiments with ${ }^{238} \mathrm{Pu}$-Bearing Materials ......................................................... 3.15

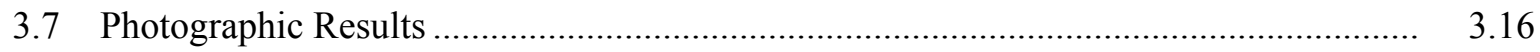

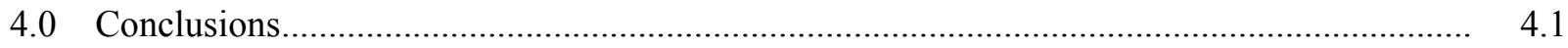

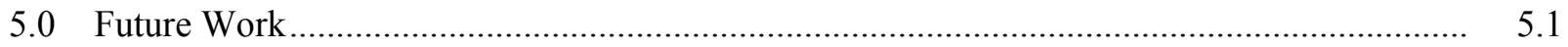

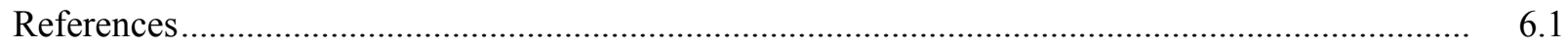

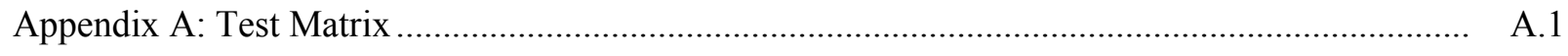

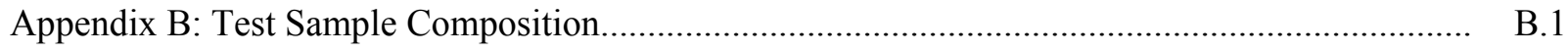

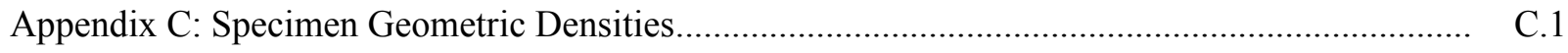




\section{Figures}

2.1. An Exploded View of the XRD Specimen Holder

2.2. Photograph of Laser-Based Device for Measuring Specimen Dimensions

2.3. Schematic Illustration of Single-Pass Flow-Through Apparatus Used in this Study

3.1. Cumulative Doses for ${ }^{238} \mathrm{Pu}$-Bearing Test Specimens

3.2. Bulk Densities for ${ }^{238} \mathrm{Pu}$-Bearing Specimens Stored at Ambient Temperatures

3.3. Bulk Densities for ${ }^{238} \mathrm{Pu}$-Bearing Test Specimens Stored at $125^{\circ} \mathrm{C}$

3.4. "True" Densities for Ceramic Materials Stored at Ambient Temperatures as Measured with a He Gas Pycnometer.

3.5. "True" Densities for Ceramic Materials Stored at $125^{\circ} \mathrm{C}$ as Measured with a He Gas Pycnometer

3.6. Diffraction Patterns for the Pure-Phase Pyrochlore Ceramic

3.7. Progression of Radiation Damage in Pyrochlore Specimens for all Storage Temperatures....

3.8. XRD from Pyrochlore that Was Stored at $250^{\circ} \mathrm{C}$ for Approximately $1 \mathrm{yr}$

3.9. Progression of Radiation Damage in Impure Baseline Ceramic Stored at Room Temperature

3.10. Series of XRD Patterns from ${ }^{238} \mathrm{Pu}$-Bearing Z-Baseline Ceramic Specimens Showing Lack of Reproducibility in the Intensity of the Diffraction Peaks Below $20^{\circ}$ Two Theta........

3.11. Two Recent XRD Patterns Showing the Persistence of the Strong Diffraction Lines Below $20^{\circ}$ Two Theta

3.12. Series of XRD Patterns from ${ }^{238} \mathrm{Pu}$-Bearing Zirconolite Showing Effect of Radiation Damage.

3.13. Effect of Expansion in c Dimension of Zirconolite Unit Cell on Reflections in Calculated XRD Pattern.

3.14. Diffraction Patterns Showing Progress of Radiation Damage in 238Pu-Bearing Pyrochlore-Baseline Ceramic Specimens Stored at Ambient Temperatures

3.15. Plot of $\log 10$ Concentration (A) and $\log 10$ Rate (B) Versus Time for Experiments with ${ }^{239} \mathrm{Pu}$-Bearing Pyrochlore Baseline Ceramics at $90^{\circ} \mathrm{C}, \mathrm{pH}=2$ 
3.16. Plot of $\log 10$ Dissolution Rate Versus Solution $\mathrm{pH}$ for Experiments with ${ }^{239} \mathrm{Pu}$-Bearing Pyrochlore Baseline Ceramics

3.17. Pot $\log 10$ Concentration (A) and $\log 10$ Rate (B) Versus Time for Experiments with ${ }^{238} \mathrm{Pu}$-Bearing Pyrochlore Baseline Ceramics, $\mathrm{T}=90^{\circ} \mathrm{C}, \mathrm{pH}=2$.

\section{Tables}

2.1. Compositions of Solutions Used in SPFT Experiments

3.1. Experimental Conditions and Average Net Concentrations of Elements in Effluent Solutions from SPFT Experiments with ${ }^{238} \mathrm{Pu}$ - and ${ }^{239} \mathrm{Pu}$-Bearing Pyrochlore Baseline (Pbase) Ceramics at $90^{\circ} \mathrm{C}$

3.2. Steady-State Dissolution Rates and Associated 2-s Uncertainties from SPFT Experiments with ${ }^{238} \mathrm{Pu}$ - and ${ }^{239} \mathrm{Pu}$-Bearing Pyrochlore Baseline (Pbase) Ceramics at $90^{\circ} \mathrm{C}$ 



\subsection{Introduction}

Some fraction of the $\mathrm{Pu}$ that the United States has declared as being surplus to its defense needs is to be converted to a titanate ceramic in the form of disks. In December 1999, approximately 200 test specimens were made to study the effect of radiation damage on the behavior of titanate ceramics proposed for immobilizing $\mathrm{Pu}$ (Strachan et al. 2000). These ceramic disks are to be placed in stainless steel cans that will be loaded into magazines. The magazines will be placed in an otherwise standard high-level waste canister, and the canisters will be filled with high-level waste glass at the defense waste processing facility at the Savannah River Site in Aiken, South Carolina.

In this document, we describe experiments that are being performed at Pacific Northwest National Laboratory in southeastern Washington State to address questions concerning the long-term behavior of the titanate ceramic in a repository environment. As part of the licensing process for the national mined geologic nuclear waste repository, a safety case is being used in which the titanate ceramic under the worst-case scenario is assumed to interact with water and degrade (TRW 1997). Under certain conditions, incongruent release or transport of fissile $\mathrm{Pu}$ and ${ }^{235} \mathrm{U}$ relative to the neutron absorbers Gd and Hf could lead to local and/or far-field nuclear criticality in the repository. To assess the possibility of this occurring, the U.S. Department of Energy (DOE) Office of Civilian Radioactive Waste Management (RW) needs information on the degradation behavior of the ceramic.

Extensive tests to determine the degradation behavior of the as-fabricated ceramic (i.e., not radiationdamaged) have been conducted as part of the Plutonium Immobilization Program. However, the decay of

${ }^{239} \mathrm{Pu}$ to ${ }^{235} \mathrm{U}$ is expected to cause the loss of crystallinity in the titanate ceramic from radiation damage on a timescale of hundreds to thousands of years. This damage will be accompanied by swelling and potential cracking of the ceramic. Both the loss of crystallinity and the potential increase in surface area from cracking could increase the rate at which the ceramic degrades. Thus, it is important to investigate and document the effects of radiation damage because a ceramic in a repository will have suffered extensive radiation damage by the time waste packages begin to fail and potentially expose their contents to groundwater. In the work reported here, characterization and testing is being performed to address the swelling and cracking and changes in dissolution behavior as self-irradiation occurs. The use of ${ }^{238} \mathrm{Pu}$ with a decay half-life $(87.7 \mathrm{yr})$ that is about 300 times shorter than ${ }^{239} \mathrm{Pu}\left(2.41 \cdot 10^{4} \mathrm{yr}\right)$ allows these studies to be performed in a reasonable time in the laboratory.

Radiation damage can be artificially induced with heavy-ion or electron bombardment (Weber et al. 1998). Although heavy-ion bombardment is supposed to result in effects that simulate self-irradiation from ${ }^{238} \mathrm{Pu}$ or ${ }^{244} \mathrm{Cm}$, the depth to which the material is rendered amorphous is small, on the order of $10 \mu \mathrm{m}$, depending on the ion being used. The self-irradiation technique was selected for these tests because some of the irradiation effects, such as cracking, cannot be simulated with external radiation sources.

To date, the results from the above-described tests/characterization indicate that the ceramic is swelling, but the swelling depends on the storage temperature and the dominant mineral that constitutes the ceramic specimen. There is no evidence of cracking, and the ceramic material appears competent, i.e., is strong enough to withstand moderate forces during handling. Of the minerals in the phase assemblage in these test specimens, pyrochlore becomes metamict over the course of $1 \mathrm{yr}$. Zirconolite is more 
resistant to damage; it converts to a pyrochlore or fluorite that is amorphous on transformation. Dissolution of the ceramic appears to be consistent between the static (MCC-1) and dynamic (single-pass flow-through) tests and shows that the ceramic containing ${ }^{238} \mathrm{Pu}$ dissolves over 100 times more rapidly than the equivalent ceramic with ${ }^{239} \mathrm{Pu}$.

In this report, we briefly describe the experimental set up, but this subject is covered more completely in the report by Strachan et al. (2000). A new test that was performed as part of a safety review of the program test procedures is described. We then discuss the results, suggest some future work, and make interim conclusions based on the results to date. 


\subsection{Experimental Methods}

Although the experimental methods used in this study are reported in Strachan et al. (2000) and McGrail and Peeler (1995), we briefly describe them here. The test materials and test matrix are shown in Appendix A and B. Of the 200 specimens that were produced, 130 have ${ }^{238} \mathrm{Pu}$ and 70 have ${ }^{239} \mathrm{Pu}$, each at concentrations between 7.4 mass \% and 11 mass\% (Strachan et al. 2000 and Appendix A). Selfirradiation from the ${ }^{238} \mathrm{Pu}$ began in October 1999. Specimens that were produced earlier than October were heated to $1100^{\circ} \mathrm{C}$ for $1 \mathrm{~h}$ to anneal any damage that had occurred between the date they were made and October. The test specimens were divided into three groups with one group each stored at room temperature (nominally $25^{\circ} \mathrm{C}$ ), $125^{\circ} \mathrm{C}$, and $250^{\circ} \mathrm{C}$ (Strachan et al. 2000 and Appendix B). The specimens are characterized and tested periodically. Characterization consists of photography, bulk density measurements based on the specimen external dimensions, "true" density measurements based on gas pycnometry, and x-ray diffraction. Testing consists of static dissolution tests of 3-d duration at $90^{\circ} \mathrm{C}$ in pure water and single-pass flow-through (SPFT) tests at $90^{\circ} \mathrm{C}$ and a $\mathrm{pH}$ value of 2 . The SPFT test is run continuously to monitor the change in dissolution as a function of time and to minimize the effect of radiolysis on the test solution. The latter is also the reason that the static test is of short duration.

Obtaining a variance to work with quantities of $\mathrm{Pu}$ in excess of those listed in the standard work procedures has facilitated work with the ${ }^{238} \mathrm{Pu}$-bearing specimens. If this work had to be performed in a glove box, it would take several times longer to perform each characterization and test. Under the variance, all of this work has been carried out in an open-faced fume hood. As these test specimens aged, it seemed prudent to determine if these specimens had become friable to the point of not withstanding normal handling operations during characterization and testing. A series of tests was performed to determine, under controlled conditions, if microscopic flakes of the ceramic could be found in the immediate surroundings of where a specimen had been placed or handled. A specimen was placed on a clean paper towel. After 10 and $20 \mathrm{~min}$, the specimen was removed and the surroundings, except immediately under the specimen, were found to contain no activity. With a clean paper towel, the specimen was placed onto the paper and returned to a sample vial 10 times. No activity was found in the surroundings except where the specimen was placed. To obtain x-ray diffraction patterns, the specimen was placed into the X-ray diffraction (XRD) specimen holder (see below) and positioned by use of an alignment jig. Alignment involves pressing on the specimen with some force. No activity was found anywhere on the specimen holder base except where the specimen had been resting and on the alignment jig. The results of this test suggest that the ceramic remains mechanically competent after about $1.5 \mathrm{yr}$ of radiation damage.

Since the last report, two devices have been constructed to facilitate the characterization. The XRD analyses are made possible with a device to hold the individual test specimens. Bulk density measurements are made with a laser micrometer-based device. Both devices are briefly described here. 
Characterization with XRD is made on the same specimen at each characterization. This is done on a XRD unit that is not contaminated with radioactive material. The XRD specimen holder is shown in Figure 2.1. It is constructed of a carbon-filled plastic that facilitates the removal of static charge that could result in the dispersal of any loose material. The specimen is mounted on the post in the base with a piece of Post-it ${ }^{\circledR}$ under the specimen and a piece of modeling clay between the paper and the post. The sticky side of the Post-it notepaper is toward the specimen and keeps the clay from getting on the specimen. Experience shows that clay is not easily removed from the test specimen, but easily removed from non-radioactive materials. An alignment jig is used to align the specimen surface to be coplanar with the upper part of the holder base. A piece of Kapton ${ }^{\circledR}$ film is used as a "window" and is held in place between the window band and the cap. An air-

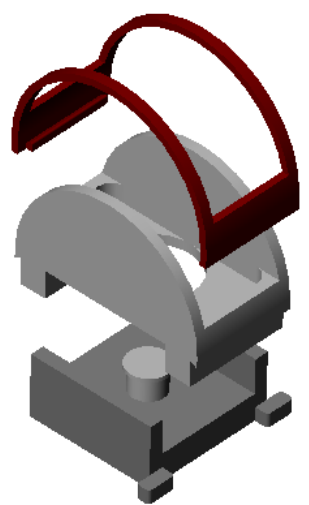

Figure 2.1. An Exploded View of the XRD Specimen Holder. Not pictured is the Kapton ${ }^{\circledR}$ film that goes between the retaining band (top part) and the cap (middle part). Also not shown is the sample cup for powder samples. setting cyanoacrylate glue is used to seal the window and window band to the cap. The cap assembly fits snugly over the base and forms a good seal. No contamination leaks from this holder even after 3 months with a ${ }^{238} \mathrm{Pu}$ specimen in place. This device is designed specifically for the Scintag PAD V x-ray unit. The "dog ears" on the base and the dimensions of the base allow the assembled holder with specimen to be placed correctly in the unit repeatedly with great precision and with a minimum of handling, thereby reducing exposure of the extremities to radiation.

The bulk, or geometric, density determinations require that the external dimensions of the test specimens be measured accurately. However, the size of the specimens and the radiation make handling the ${ }^{238} \mathrm{Pu}$-bearing test specimens cumbersome and hazardous, the hazard coming from the intense radiation that comes from the specimens. Additionally, any handling of the specimens had to be done in a glove box with the thick gloves that are usually found in these boxes. We found during the early part of the study that we got poor accuracy and precision when measuring the dimensions with hand-held micrometers. To alleviate these two conditions (extremity dose and poor accuracy and precision), we developed the apparatus shown in Figure 2.2. The device consists of two laser curtains with paired sensors. The sensors contain 5000 diodes that span $35 \mathrm{~mm}$. Each diode intercepts approximately $1 \mathrm{~mm}$ of laser light perpendicular to the main axis of the diode array. One of these laser-sensor pairs is in the horizontal orientation and the other in the vertical. The plane of the horizontally oriented diode array is set about $0.5 \mathrm{~mm}$ above the rotating table (Figure 2.2) on which the specimen is placed. The vertical pair is positioned such that the plane of the diodes just intersects the rotating table. Thus, the horizontal pair is used to measure the diameter of the test specimen and the vertical pair the specimen height. 


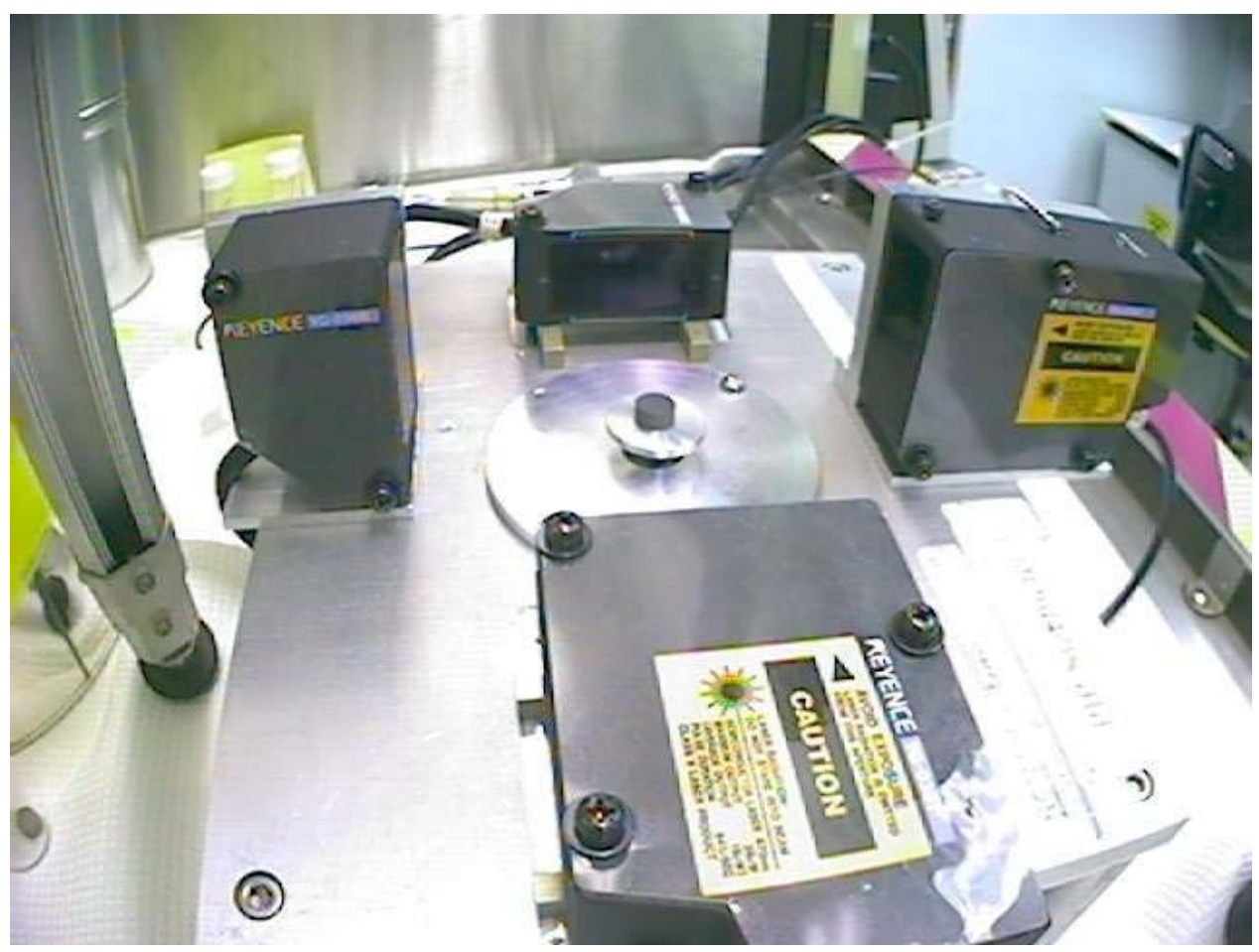

Figure 2.2. Photograph of Laser-Based Device for Measuring Specimen Dimensions. The lasers are in the foreground (diameter measurement) and the right (height measurement). The table (with specimen) is constructed of aluminum and sits on the shaft of a small motor that rotates at about $10 \mathrm{rpm}$.

The frequency at which the sensors operate is 12000 measurement $/ \mathrm{s}^{-1}$. We set the controller to collect 4 measurements that are averaged and sent to a computer. At the computer, the measurements are collected into a spreadsheet. We make measurements over $45 \mathrm{sec}$, during which time the specimen rotates 4 to 5 revolutions, and more than 3500 measurements (each an average of 4 measurements) of the diameter and height are recorded. Two stainless steel disks with dimensions approximately those of the ${ }^{238} \mathrm{Pu}$ - and ${ }^{239} \mathrm{Pu}$-bearing specimens are used to determine instrument drift. A calibrated laser micrometer was used to obtain the dimensions of the stainless steel disks.

Specimen bulk densities are obtained from the dimensions obtained with the laser-based device described above and the specimen mass.

"True" densities are the densities without the specimen open porosity. These are determined with a He gas pycnometer (Micromeretics AccuPyc 1330). Densities are determined with three specimens in the sample chamber. Calibrations are performed at the beginning and the end of the day.

Progression of the radiation damage on the individual crystalline phases is monitored with XRD. The settings in the unit are $45 \mathrm{kV}$ at $40 \mathrm{~mA}$ on the $\mathrm{Cu}$ tube and scan parameters of 0.04- to 0.06-degree steps at 2 to $6 \mathrm{sec}$ per step. A sample of the SRM $1976\left(\mathrm{Al}_{2} \mathrm{O}_{3}\right)$ from the National Institute of Testing and Standards that was permanently mounted in an XRD specimen holder is run at the start and the end of each day to monitor machine performance and drift. Over the past year, the intensity of the SRM 1976 diffraction peaks has decreased approximately $13 \%$. 
The MCC-1 Static Dissolution Test (ASTM 1998) protocol has been slightly modified to accommodate constraints imposed by the nature of these samples. For example, because of the specimen size and experimental restrictions in the ovens, the size of the leach vessel did not allow us to attain a surface area-to-solution volume ratio of $10 \mathrm{~m}^{-1}$. These minor modifications have been noted and do not affect the results of the experiments.

Photographs are taken with a video camera. Images are captured on the computer with an imaging program.

McGrail et al. (1997) report the experimental apparatus for the SPFT. The salient features of the SPFT apparatus used in this study are illustrated in Figure 2.3. Syringe pumps (Kloehn; model 50300) were used to transfer solution from the input reservoir bottles to the Teflon ${ }^{\circledR}$ reaction vessels. The key advantage of syringe pumps is that they can accommodate multiple fluid transfer lines. Thus, one syringe pump can deliver solution to up to four reactors so that duplicate experiments and blanks (see below) can be run simultaneously. A nitrogen generator is used to continuously supply $\mathrm{N}_{2}$ to the solution reservoirs to mitigate a drift in the solution $\mathrm{pH}$ that would occur if atmospheric $\mathrm{CO}_{2}$ were present above the solutions.

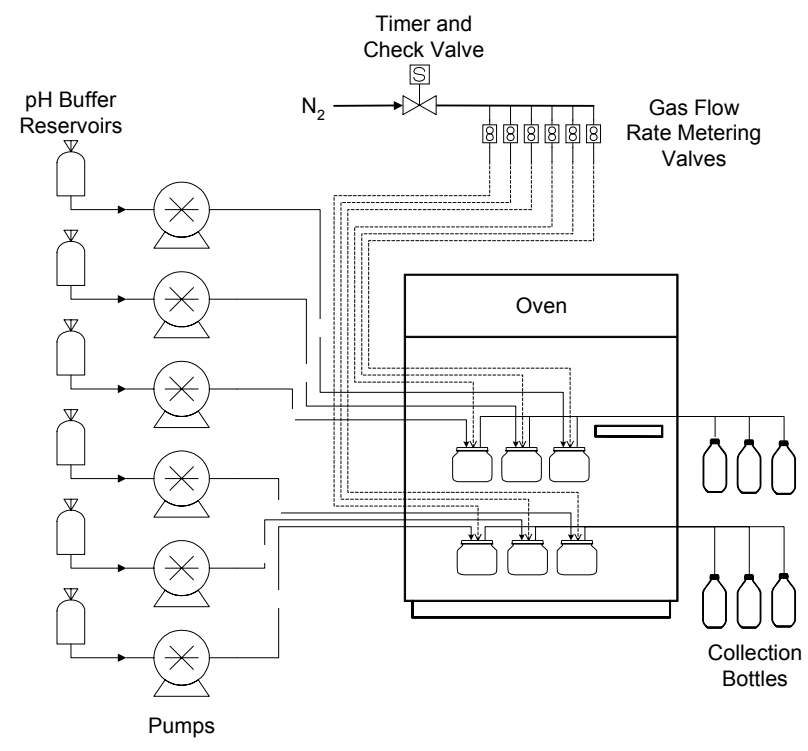

Figure 2.3. Schematic Illustration of Single-Pass Flow-Through Apparatus Used in this Study

In the experiments described here, the oven temperature is $90^{\circ} \mathrm{C}$. A digital thermocouple, accurate to $\pm 2^{\circ} \mathrm{C}$, was used to record oven temperature daily. The reactor vessels have lids with two ports through which Teflon ${ }^{\mathbb{B}}$ tubes pass for solution input and for leachate removal. The powdered ceramic sample lies at the bottom of the reactor in a thin layer. Therefore, the fluid is not pumped directly through the sample, as in other reactor designs. The advantage of this design is that bubbles that form in the fluid transfer lines do not become entrained in the sample. Entrainment would alter the surface area of the specimen exposed to the solution. Effluent was accumulated continuously in collection bottles situated outside the oven.

For the experiment with the ${ }^{238} \mathrm{Pu}$-bearing specimen, a slightly modified SPFT reactor vessel was needed. We found that if the specimen were allowed to come in direct contact with the Teflon ${ }^{\circledR}$ reactor vessel, fluoride was released because of the radiation damage to the Teflon ${ }^{\circledR}$. To prevent radiation damage to the Teflon ${ }^{\circledR}$, a platinum liner was placed inside of the vessel. The insert was tall enough to protect the interior of the reactor so that the only Teflon ${ }^{\circledR}$ in contact with the solution was that associated with the influent and effluent lines.

Aliquots of effluent solution were routinely checked to ensure that $\mathrm{pH}$ control was maintained during the experiment. As discussed below, $\mathrm{pH}$ control was maintained, with one exception. Other aliquots 
were reserved for radiochemical assay with counting techniques. Gamma energy analyses (GEAs) were used to analyze for ${ }^{239} \mathrm{Pu},{ }^{238} \mathrm{Pu},{ }^{240} \mathrm{Pu},{ }^{241} \mathrm{Pu}$, and ${ }^{241} \mathrm{Am}$ in an aliquot of the leachate. The remainder of the effluent was acidified $(\mathrm{pH}<2)$ with high purity nitric acid and analyzed for $\mathrm{Gd}, \mathrm{Hf}, \mathrm{Mo},{ }^{239} \mathrm{Pu}$, Ti, and $\mathrm{U}$ concentrations with inductively coupled plasma-mass spectroscopy (ICP-MS). Concentrations of Al and $\mathrm{Ca}$ in with the leachates from ${ }^{239} \mathrm{Pu}$-bearing ceramics were determined with optical emission spectroscopy (ICP-OES) methods. This technique was not used for leachates from ${ }^{238} \mathrm{Pu}$ specimens because the ICPOES was not set-up to handle solutions having high activity.

Typically, three blank solutions were drawn before the specimen was added to the reactor. The blank solutions were analyzed for background concentrations of elements of interest and, together with analyses of starting solution aliquots, ensured us that contamination from previous experiments was not a factor. Blanks, which were set up identically to the other reaction cells, but without a test specimen, were used to monitor the Mo in the starting $\mathrm{pH}$-buffered leach solutions. Analyses of the solutions from the blanks showed that the concentrations of Mo remained relatively low until evaporation of the input solution in the reservoir caused Mo concentrations to rise. As noted in Figure 2.3, the reservoirs were purged with $\mathrm{N}_{2}$. Some evaporation of the leachant was expected, especially as the reservoir reached empty. In most cases, reservoir bottles were exchanged before significant evaporation occurred. Any slight rise in background Mo concentrations was recorded, and these concentrations dropped to near detection level $(\sim 0.10 \mathrm{ppb})$ after the reservoir was changed. The concentration of Mo from the blank was subtracted from the Mo concentration in the leachate from the test specimens.

We calculate dissolution rates from the leachate concentrations. These rates are normalized to the amount of the element present in the ceramic and calculated with the formula:

$$
r_{i, j}=\frac{\left(C_{i, j}-\bar{C}_{i, b}\right) q_{j}}{f_{i} S_{j}}
$$

where

$$
\begin{aligned}
r_{i, j} & =\text { the normalized release rate }\left[\mathrm{g} /\left(\mathrm{m}^{2} \cdot \mathrm{d}\right)\right] \text { based on element } i \text { at the } j^{t h} \text { sampling } \\
C_{i, j} & =\text { the concentration }\left(\mathrm{g} \cdot \mathrm{m}^{-3}\right) \text { of the element, } i, \text { in the effluent at the } j^{\text {th }} \text { sampling } \\
\bar{C}_{i, b} & =\text { the average background concentration }\left(\mathrm{g} \cdot \mathrm{m}^{-3}\right) \text { of the element of interest } \\
q_{j} & =\text { the flow rate }\left(\mathrm{m}^{3} \cdot \mathrm{d}^{-1}\right) \text { at the } j^{t h} \text { sampling } \\
f_{i} & =\text { the mass fraction of the element in ceramic (dimensionless) } \\
S_{j} & =\text { the average surface area }\left(\mathrm{m}^{2}\right) \text { of the specimen over the time period } j-1 \text { to } j .
\end{aligned}
$$

The detection threshold of any element is defined here as the lowest concentration calibration standard that can be determined reproducibly (within 10\%) during an analytical run. In cases where the analyte is below the detection threshold, the background concentration of the element is set at the value of the detection threshold, even though the concentration of the element could be much lower. For most elements (Gd, Pu, U, Mo, and Hf), the detection threshold is $\sim 0.10 \mathrm{ppb}$. Higher detection thresholds were determined for $\mathrm{Ti}$ (up to $5 \mathrm{ppb}$ ) and $\mathrm{Ca}$ (up to $10 \mathrm{ppb}$ ). Only in the case of $\mathrm{Ca}$ were background concentrations consistently detected; these ranged as high as $80 \mathrm{ppb}$. Flow rates are determined from the mass of leachate collected in each effluent collection vessel upon sampling. The value of $f_{i}$ is calculated 
from the chemical composition of the ceramic. Changes in surface area of the sample during the experiment were estimated as described by McGrail and Peeler (1995). In all cases, such surface area corrections were negligible. Experimental uncertainties for the SPFT were determined with a propagation-of-errors analysis. The relative errors $(\sigma)$ in the apparent rates are given by the formula:

$$
\hat{\sigma}_{r}=\sqrt{\frac{\left(\hat{\sigma}_{c} C_{i, j}\right)^{2}+\left(\hat{\sigma}_{b} \bar{C}_{i, b}\right)^{2}}{\left(C_{i, j}-\bar{C}_{i, b}\right)^{2}}+\hat{\sigma}_{q}^{2}+\hat{\sigma}_{f_{i}}^{2}+\hat{\sigma}_{S}^{2}}
$$

The uncertainties in $C_{i}, \bar{C}_{i, b}, q, f_{i}$, and $S$ are $10 \%, 10 \%, 10 \%, 5 \%$, and $15 \%$, respectively. The resulting experimental uncertainties in the rate measurements are 30 to $40 \%$, but are more typically on the order of $20 \%$. The variation in values is controlled by the difference between the concentration of the element in solution to that of the background. When the difference is small, the calculated uncertainty increases.

The chemical durability of the ${ }^{238} \mathrm{Pu}$-bearing pyrochlore baseline ceramic was tested in $\mathrm{pH}=2$ solution. Six solutions at $\mathrm{pH}$ values of $2,7,8,9,10$, and 11 were used for the experiments with ${ }^{239} \mathrm{Pu}-$ bearing pyrochlore-rich baseline materials (Table 2.1). Reagent-grade nitric acid was mixed with deionized water (DIW) to yield acidic solution $(\mathrm{pH}=2)$. Neutral to slightly basic solutions $(\mathrm{pH}=7,8,9$, and 10) were made by mixing small amounts of the organic THAM (tris hydroxymethyl aminomethane) buffer to DIW and then adding ultrapure $\mathrm{HNO}_{3}$ to bring the solution to the desired $\mathrm{pH}$ value. Alkaline solutions $(\mathrm{pH}=11)$ were prepared by adding $\mathrm{LiCl}$ and $\mathrm{LiOH}$ to $\mathrm{DIW}$. In Table 2.1 , the $\mathrm{pH}$ at $90^{\circ} \mathrm{C}$ is also shown. This $\mathrm{pH}$ value was calculated with the EQ3NR computer code (Wolery 1992). As one can see from Table 2.1, the in-situ $\mathrm{pH}$ of the experiment can change by as much as $1.5 \mathrm{pH}$ units over the temperature interval of $23^{\circ}$ to $90^{\circ} \mathrm{C}$.

Table 2.1. Compositions of Solutions Used in SPFT Experiments. Solution $\mathrm{pH}$ values at $90^{\circ} \mathrm{C}$ were calculated with EQ3NR Code V7.2b database.

\begin{tabular}{||c|c|c|l||}
\cline { 2 - 3 } \multicolumn{1}{c|}{} & Target & Estimated & \multicolumn{1}{c||}{} \\
\hline \hline Solution \# & $\mathbf{p H ~}\left(\mathbf{2 5}^{\mathbf{9}} \mathbf{C}\right)$ & $\mathbf{p H}\left(\mathbf{9 0} \mathbf{C}^{\mathbf{C}}\right)$ & Composition \\
\hline 1 & 2.0 & 2.0 & $0.01 \mathrm{M} \mathrm{HNO}_{3}$ \\
\hline 2 & 7.0 & 5.5 & $0.01 \mathrm{M} \mathrm{THAM}+0.009 \mathrm{M} \mathrm{HNO}_{3}$ \\
\hline 3 & 8.0 & 6.5 & $0.01 \mathrm{M} \mathrm{THAM}+0.006 \mathrm{M} \mathrm{HNO}_{3}$ \\
\hline 4 & 9.0 & 7.3 & $0.01 \mathrm{M} \mathrm{THAM}+0.003 \mathrm{M} \mathrm{HNO}_{3}$ \\
\hline 5 & 10.0 & 9.2 & $0.01 \mathrm{M} \mathrm{THAM}+0.001 \mathrm{M} \mathrm{LiOH}$ \\
\hline 6 & 11.0 & 10.1 & $0.01 \mathrm{M} \mathrm{LiCl}+0.011 \mathrm{M} \mathrm{LiOH}$ \\
\hline
\end{tabular}




\subsection{Results and Discussion}

\subsection{Damage Cumulative Radiation}

Because each of the ceramic materials contained slightly different amounts of ${ }^{238} \mathrm{Pu}$, the rate at which the damage occurred is slightly different. In Figure 3.1, the cumulate damage for each ceramic material is shown as a function of time in days. The data reported in this report are for about 650 days.

Therefore, each of the pyrochlore, P-baseline, and I-baseline specimens have received approximately $3 \cdot 10^{18}$ alphas/g of specimen, about $2 \cdot 10^{18}$ alphas/g for the zirconolite, and Z-baseline specimens. According to the literature on pyrochlore and zirconolite, the pyrochlore specimens should be nearly amorphous, and the zirconolite specimens should be about $80 \%$ of the way to becoming fully amorphous (Weber et al. 1986; Weber and Matzke 1986; Wang et al. 1999a).

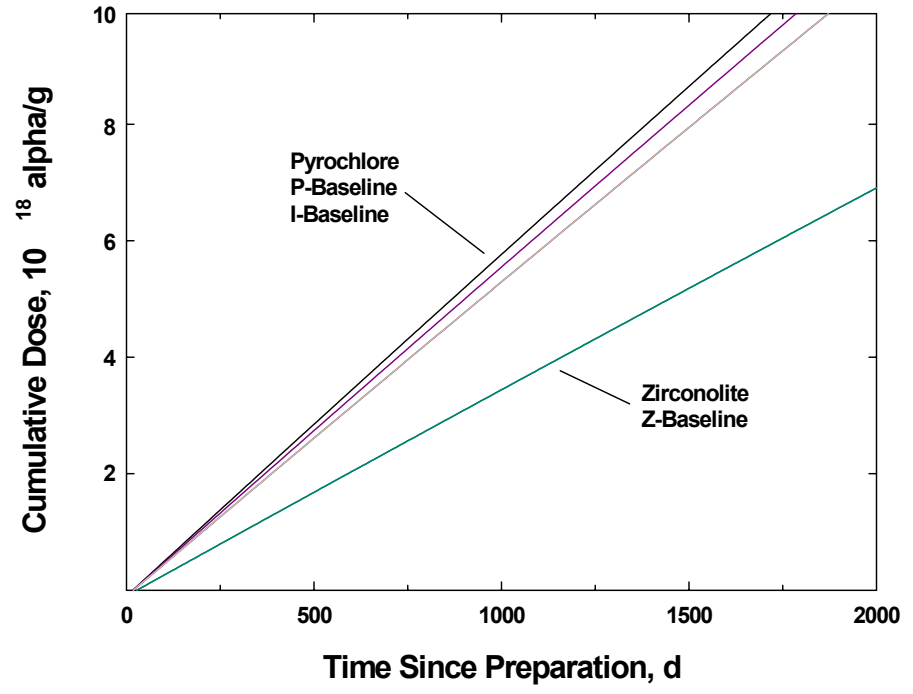

Figure 3.1. Cumulative Doses for ${ }^{238} \mathrm{Pu}$-Bearing Test Specimens

\subsection{Specimen Densities}

In Figure 3.2, the bulk densities of the ${ }^{238} \mathrm{Pu}$-bearing specimens that are stored at room temperature are shown. The measurements that were obtained at the start of the experiments (October 1999) were

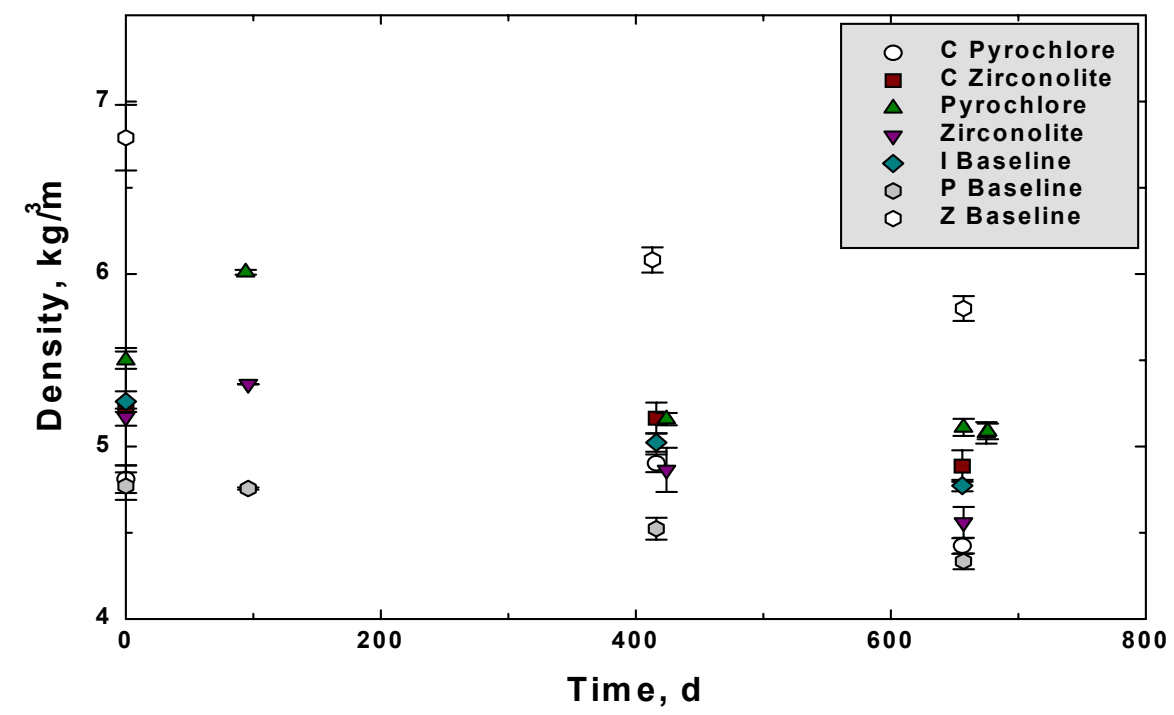

Figure 3.2. Bulk Densities for ${ }^{238} \mathrm{Pu}$-Bearing Specimens Stored at Ambient Temperatures 
obtained by use of a calibrated hand-held micrometer. Densities decrease by about $15 \%$ for the zirconolite baseline ceramic to about $8 \%$ for the pyrochlore baseline ceramic, corresponding to the measured increases in the volume of the specimens. The error bars shown on the data points in Figure 3.2 and other figures represent 1-sigma standard deviation in the average of the experimental determinations. Similar effects on the densities of the specimens stored at $125^{\circ} \mathrm{C}$ are shown in Figure 3.3. Additional data for the specimens stored at $25^{\circ} \mathrm{C}$ and $125^{\circ} \mathrm{C}$ are shown in Appendix C. The large error bars shown in the data obtained at 270 days result from the difficulty in performing measurements with hand-held micrometers.

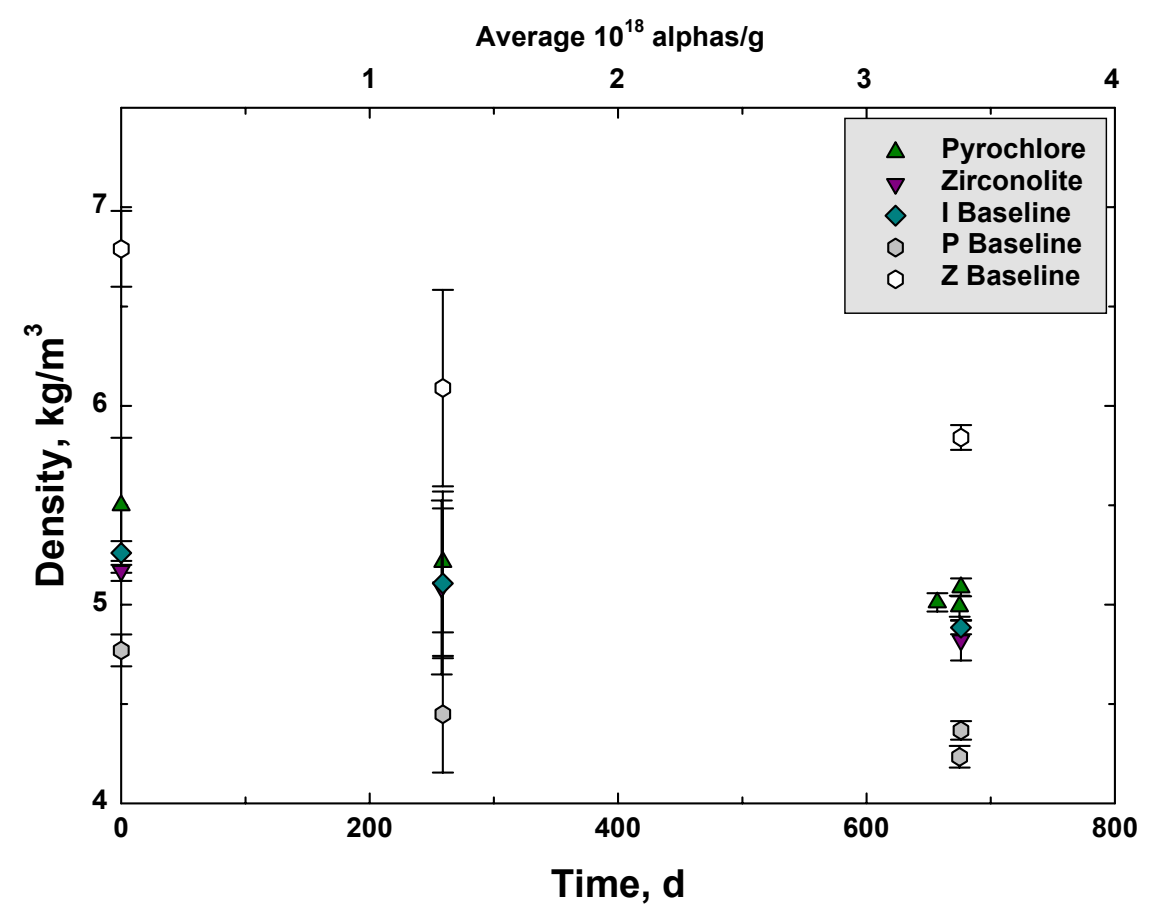

Figure 3.3. Bulk Densities for ${ }^{238} \mathrm{Pu}$-Bearing Test Specimens Stored at $125^{\circ} \mathrm{C}$

We have fewer data for the specimens stored at $250^{\circ} \mathrm{C}$. These data will be reported in the next report. In Figure 3.4 and Figure 3.5, the change in "true" density of the ceramic materials stored at room temperature and $125^{\circ} \mathrm{C}$, respectively, is shown. As with the bulk densities, the densities decrease with increasing dose. The decrease is from about $11 \%$ for the pure-phase zirconolite to about $2 \%$ for the coarse pyrochlore ceramic. 


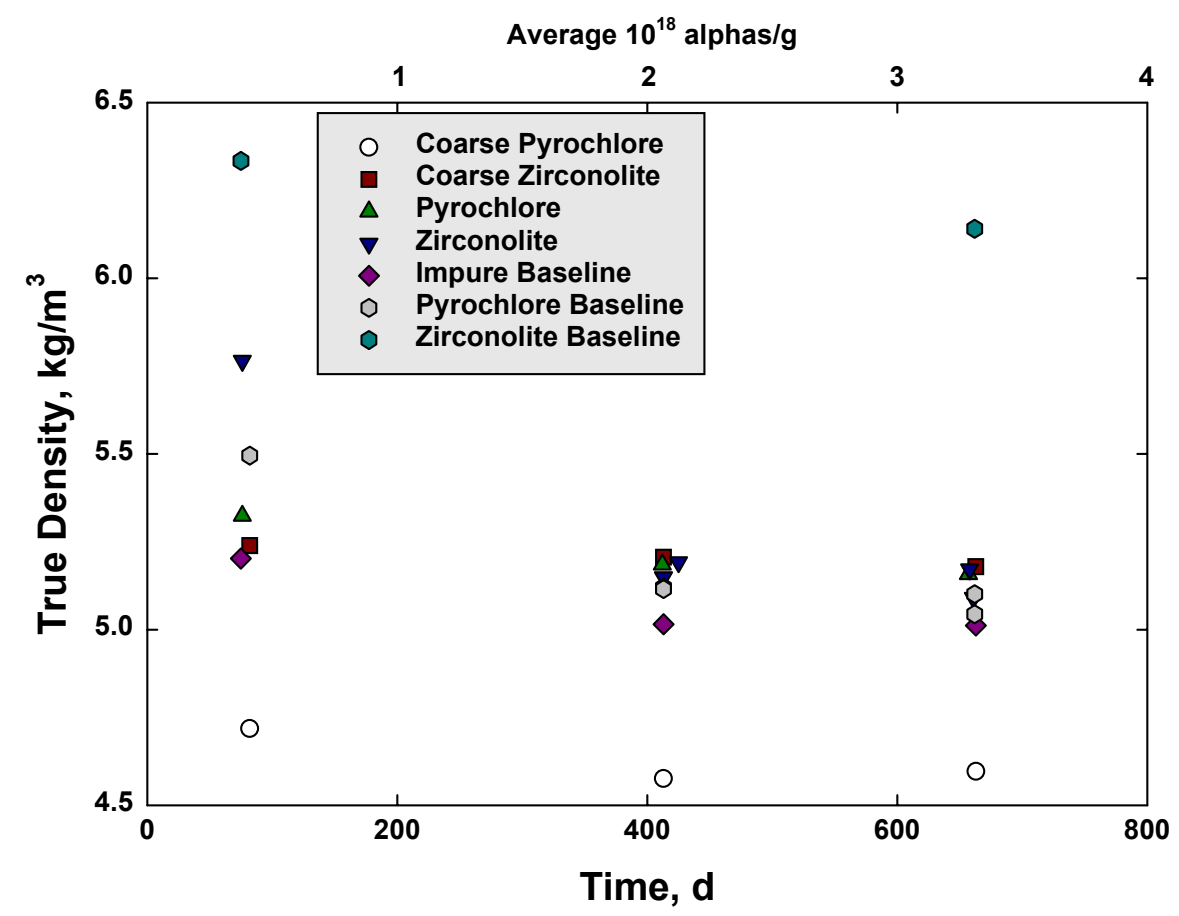

Figure 3.4. "True" Densities for Ceramic Materials Stored at Ambient Temperatures as Measured with a He Gas Pycnometer

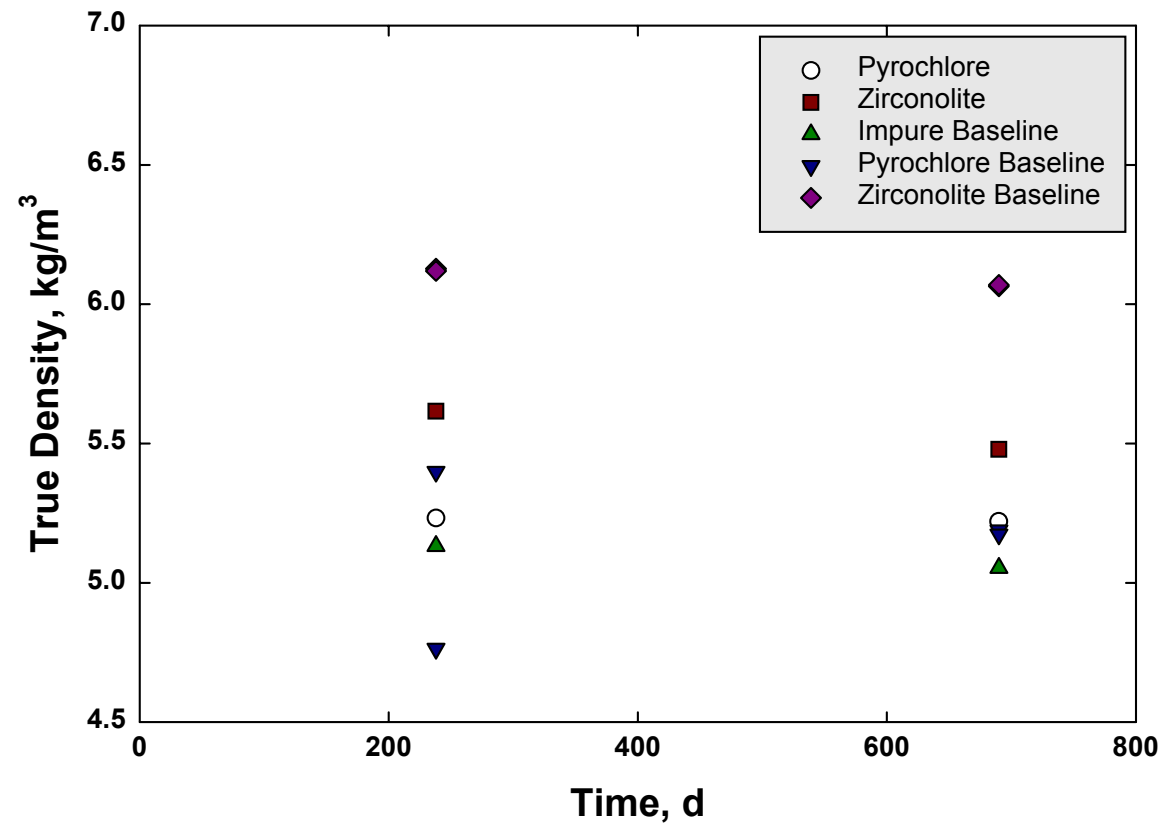

Figure 3.5. "True" Densities for Ceramic Materials Stored at $125^{\circ} \mathrm{C}$ as Measured with a $\mathrm{He}$ Gas Pycnometer 


\subsection{X-Ray Diffraction Results}

From a cursory examination of the XRD results, the most obvious effect is that pyrochlore becomes metamict (amorphous) quite rapidly. After $1 \mathrm{yr}$, the pyrochlore peaks have become quite broad and less intense. Zirconolite appears to be resistant to radiation damage. Upon transformation, the pyrochlore or fluorite to which it transforms is metamict. However, when a full complement of impurities is present, the resulting zirconolite becomes metamict about as rapidly as pyrochlore. This effect appears to be different than what is observed in heavy-ion radiation-damage studies in which the transformation from one pure phase to the other is clearly observed before the material becomes metamict (Meldrum et al. 2001; Wang et al. 1999a; Wang et al. 1999b; Weber et al. 1985; Weber et al. 1986). In these studies, pyrochlore transformed to a crystalline titanate with the fluorite crystal structure and then became metamict. Begg et al. (2000) found that the diffraction pattern from pyrochlore showed peaks that became asymmetric with increasing heavy-ion irradiation. The asymmetry was assigned to the in-growth of the fluorite structure. In our studies, none of the diffraction peaks showed this asymmetry. Rather, the peaks are found to be symmetrical.

Figure 3.6 shows the XRD pattern from the pure-phase pyrochlore stored at room temperature. The only crystalline phase that is present is the Hf-rutile, a hafnia-rutile $\left(\mathrm{HfO}_{2}-\mathrm{TiO}_{2}\right.$ solid solution with the rutile crystal structure). Ebbinghaus et al. (1999) showed that there is no appreciable solubility of $\mathrm{PuO}_{2}$ in rutile. Therefore, there should be little or no radiation damage to the Hf-rutile from the recoiling ${ }^{234} \mathrm{U}$, and the damage from the alpha particles should be small (Weber et al. 1998). Because the Hf-rutile is not damaged from the radiation and the pyrochlore is damaged, the diffraction from the Hf-rutile dominates the pattern. There is no evidence that a phase with the fluorite structure developed in the XRD patterns taken from pyrochlore specimens since the beginning of the study. This is difficult to say with certainty because the lines in the diffraction pattern become very broad and difficult to index. Figure 3.7 shows the progression of radiation damage in the pyrochlore specimens stored at all temperatures since the beginning of the study. While different x-ray diffractometer settings were used as the materials became damaged, the intensities were reduced to the same basis (e.g., the intensities in a pattern obtained at 0.06 steps/s were multiplied by 1.5 to put them on the same basis as the intensities in a pattern obtained at 0.04 steps/s). For the comparisons made to date, corrections were not made for the decreasing beam intensity. 


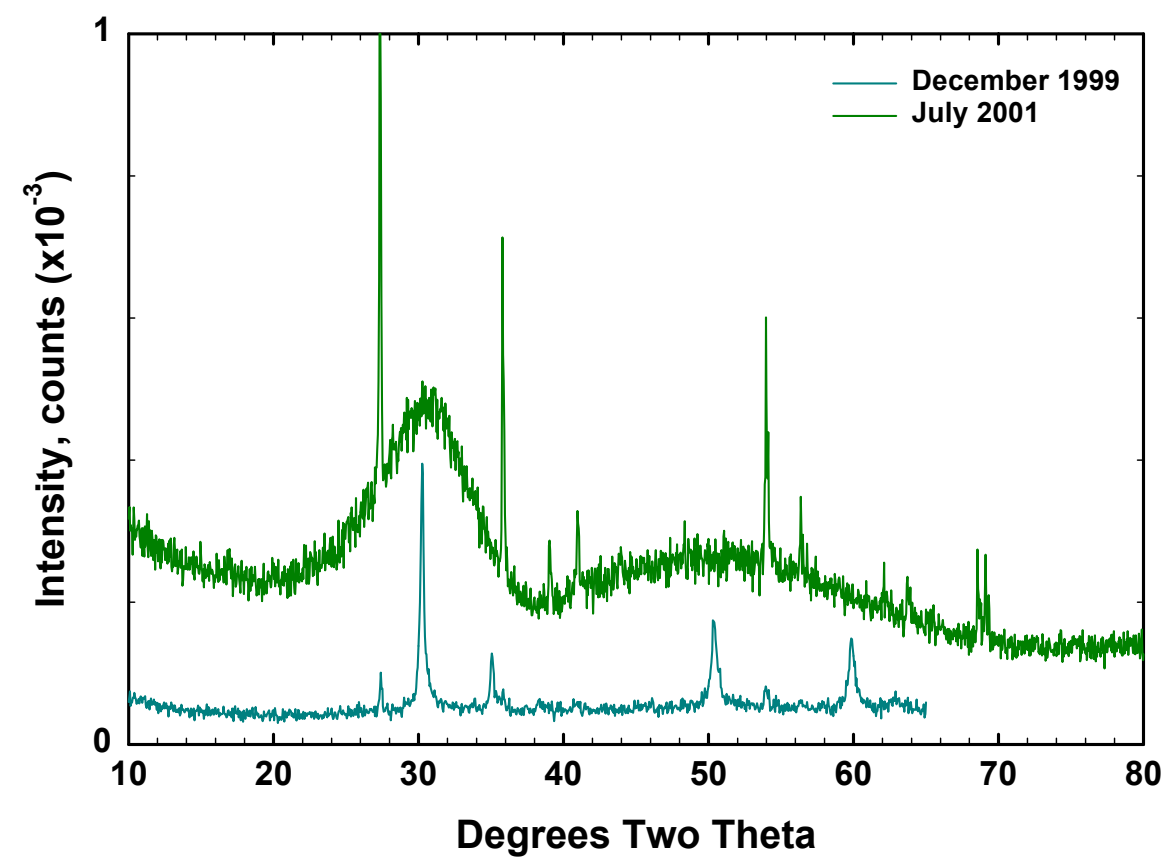

Figure 3.6. Diffraction Patterns for the Pure-Phase Pyrochlore Ceramic. The lower pattern was obtained shortly after the specimen was made. The upper pattern was obtained approximately $1.5 \mathrm{yr}$ later.

Closer examination of the XRD from the pyrochlore specimens stored at $250^{\circ} \mathrm{C}$ reveals that the pyrochlore may be transforming to zirconolite (Figure 3.8). According to Weber (private communication), $250^{\circ} \mathrm{C}$ may be very close to the critical temperature- the temperature at which radiation damage is annealed as rapidly as it occurs. Because the peaks are broad and only the strong reflections remain in the pattern, it is difficult to assign the remaining peaks to the cubic structures of pyrochlore or fluorite. Transformation of pyrochlore to zirconolite would suggest that the zirconolite (monoclinic) is stable relative to pyrochlore (cubic) for the compositions studied here. 


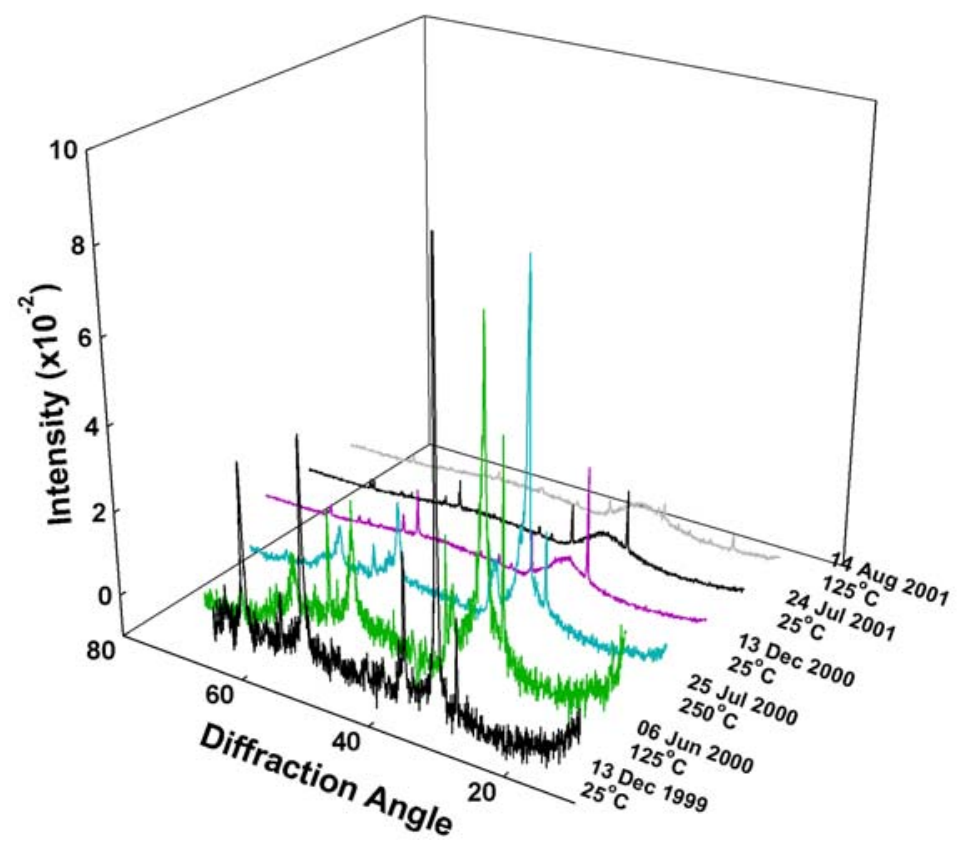

Figure 3.7. Progression of Radiation Damage in Pyrochlore Specimens for all Storage Temperatures

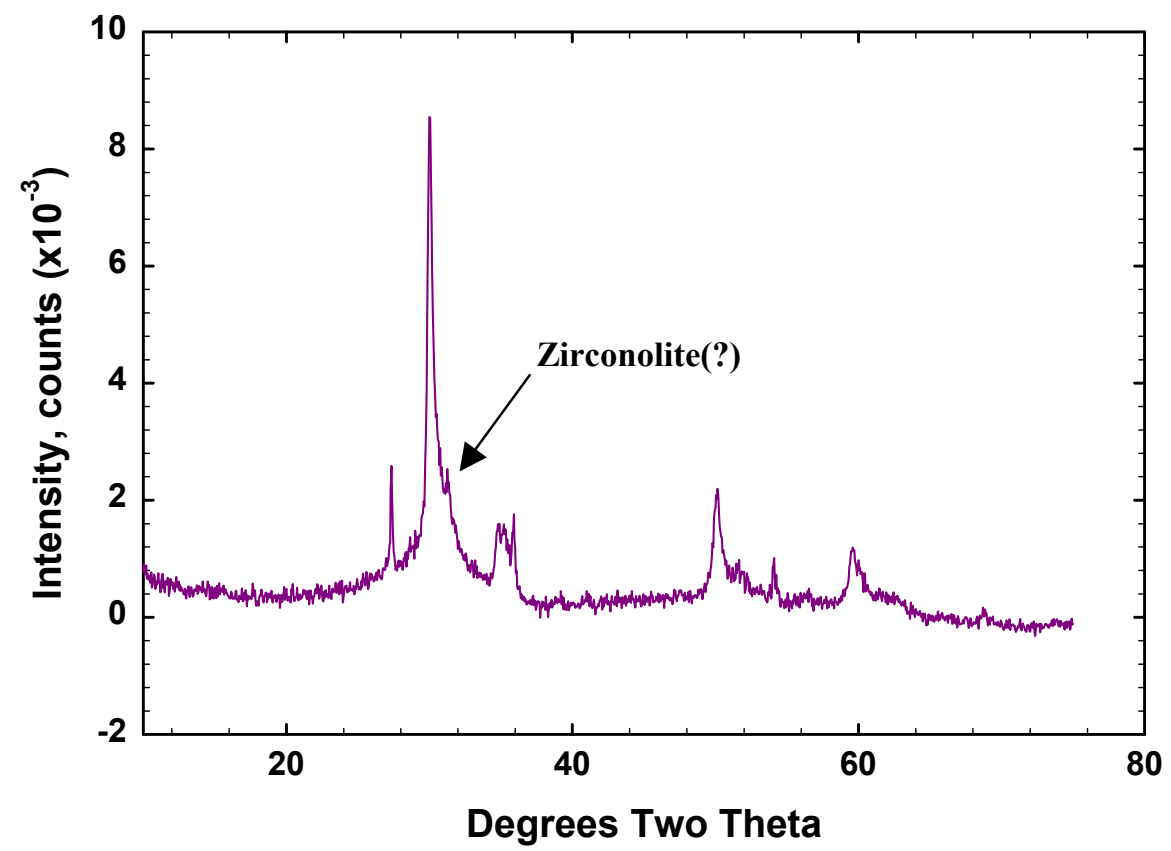

Figure 3.8. XRD from Pyrochlore that Was Stored at $250^{\circ} \mathrm{C}$ for Approximately $1 \mathrm{yr}$. The arrow points to the peak suspected to indicate the presence of a phase with the zirconolite structure. 
The XRD pattern for the baseline material with impurities (impure baseline) is shown in Figure 3.9. While the pattern shows that the majority of the crystalline material has become metamict, rutile or Hfrutile remains crystalline. A small amount of crystalline zirconolite may also be present, but this conclusion is a bit speculative because making assignments on the presence of a single peak is dangerous. Nevertheless, the XRD pattern from the initial characterization supports this assignment of the peak at about 31 degrees to the (004) zirconolite reflection. This peak moves to lower two-theta values with increasing radiation damage, i.e., the c-axis becomes longer, while the position of the main (221) peak remains in the same position. While this effect is discussed more thoroughly below, this is strong evidence that the residual diffraction is from zirconolite rather than the in-growth of the fluorite structure.

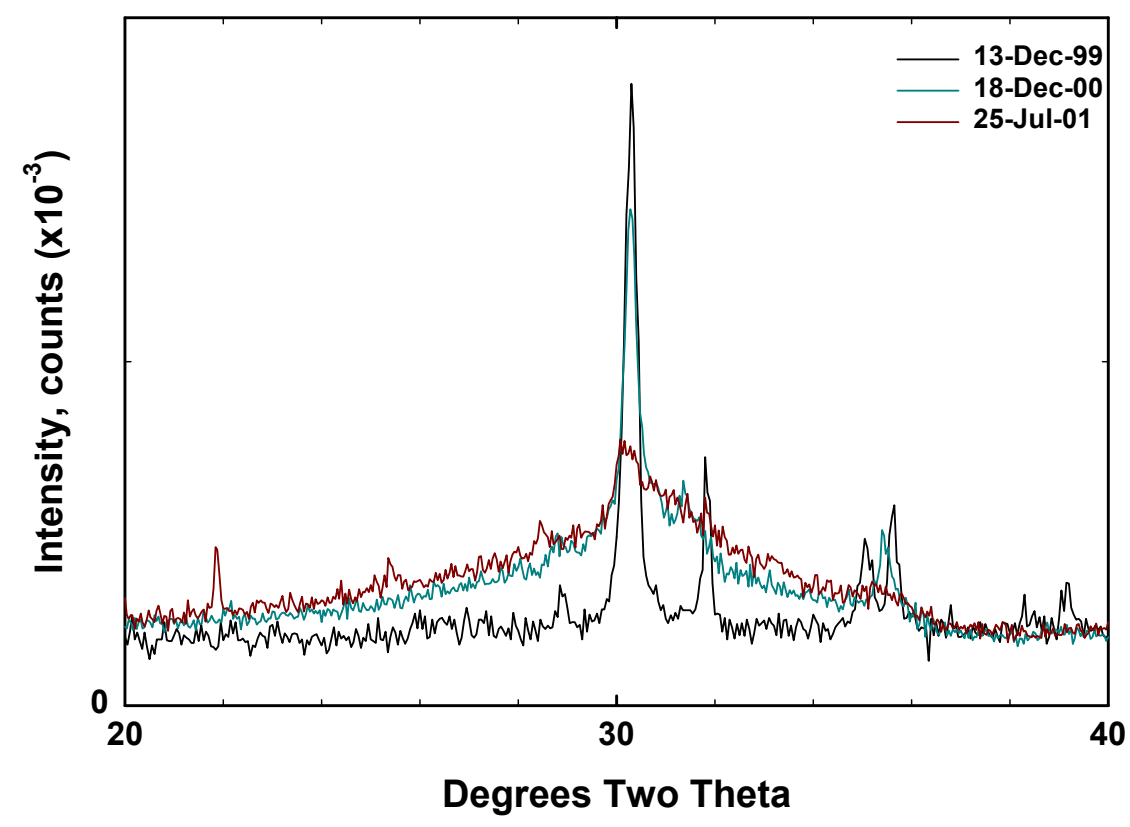

Figure 3.9. Progression of Radiation Damage in Impure Baseline Ceramic Stored at Room Temperature

For impure baseline, coarse pyrochlore, zirconolite, and zirconolite baseline (see Figure 3.10 for zirconolite as an example), the presence of very intense peaks at low two-theta values is persistent and troublesome. It is tempting to assign these peaks to problems associated with alignment of the specimen. We tested the alignment question by obtaining XRD patterns from two specimens within the same storage vessel and multiple mountings of the same specimen. The results are shown in Figure 3.10. Placing the same specimen in the specimen holder in different rotational orientations sometimes yielded the low twotheta lines and sometimes did not. The second specimen from the same storage vessel gave the same results. Between the time we performed this test and the most recent characterization, we developed a jig that gives a more positive and reproducible alignment of the specimen. As noted in Figure 3.11, the lines persist. We now feel that these lines are due to a spotty surface layer. We sometimes "see" what appears to be a spotty surface contamination, but this may simply be an effect due to lighting. Although hesitant to take the next step, we are contemplating polishing the surface to see if the lines go away. 


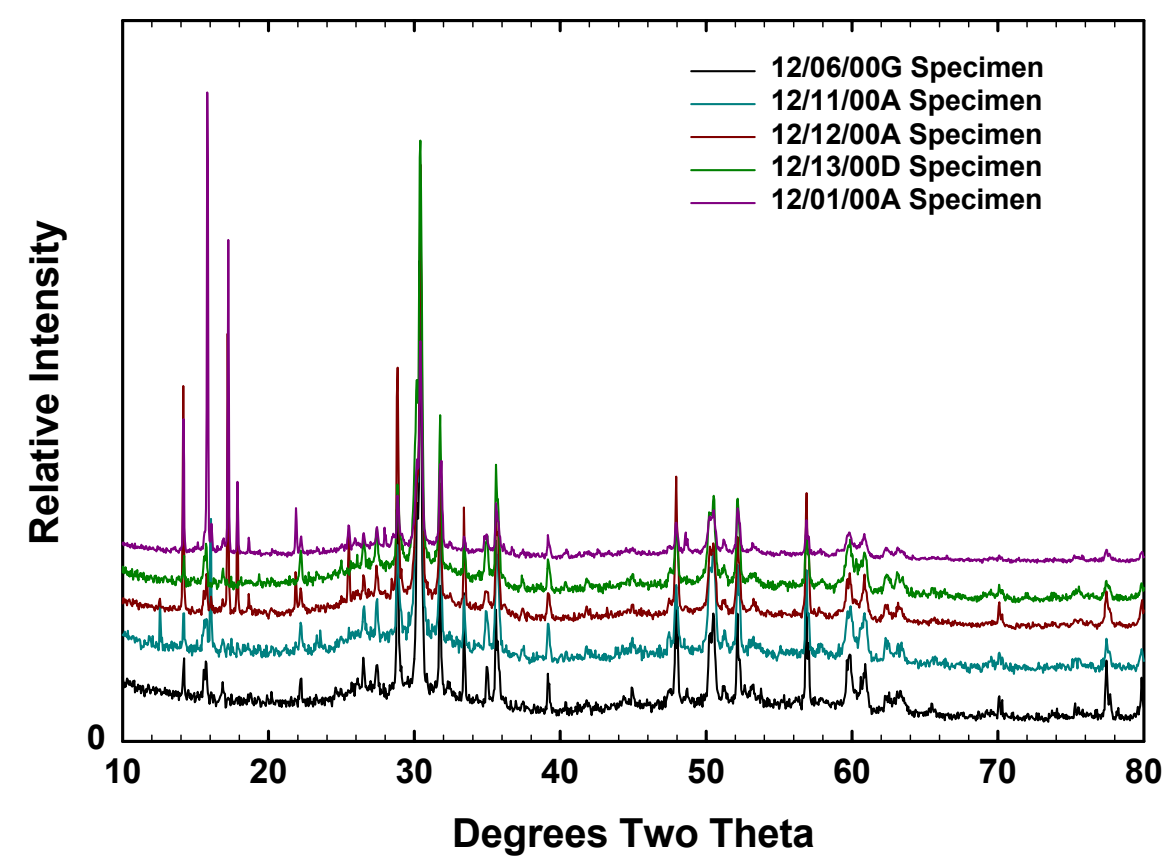

Figure 3.10. Series of XRD Patterns from ${ }^{238} \mathrm{Pu}$-Bearing Z-Baseline Ceramic Specimens Showing Lack of Reproducibility in the Intensity of the Diffraction Peaks Below $20^{\circ}$ Two Theta

As can be seen in Figure 3.12, the zirconolite specimens have become largely metamict. However, there is considerable crystallinity that can be attributed to zirconolite. Examination of earlier data (Figure 3.9) suggests that the zirconolite lattice expands predominantly in the c dimension of the monoclinic cell with small changes in the other parameters until the lattice transforms to the cubic lattice (pyrochlore). This conclusion is reached by observing the reflection from the (004) lattice plane. Because its position depends only on the $\mathrm{c}$ dimension, its position should be directly proportional to the length of the axis. We calculated the effect of increasing the $\mathrm{c}$ dimension by $2 \%, 4 \%$, and $6 \%$ without any changes to the remaining lattice parameters. The results are plotted in Figure 3.13. This was done to illustrate the effect rather than suggest that this is what happens in the actual unit cell. In the actual cell, the changes are expected to be more complicated, but the dominant effect appears to be the change in the c dimension. As can be seen in Figure 3.13, the peak from the (004) lattice plane moves to lower two theta values, as observed, eventually merging with and crossing the most intense peak (221) in the pattern. Additional support for this is observed in the positions of the peaks at about 40 degrees two theta (Figure 3.9 and Figure 3.13). These effects are difficult to prove conclusively because, as the damage occurs and the peak positions change, they also become broader, making assignment difficult. 


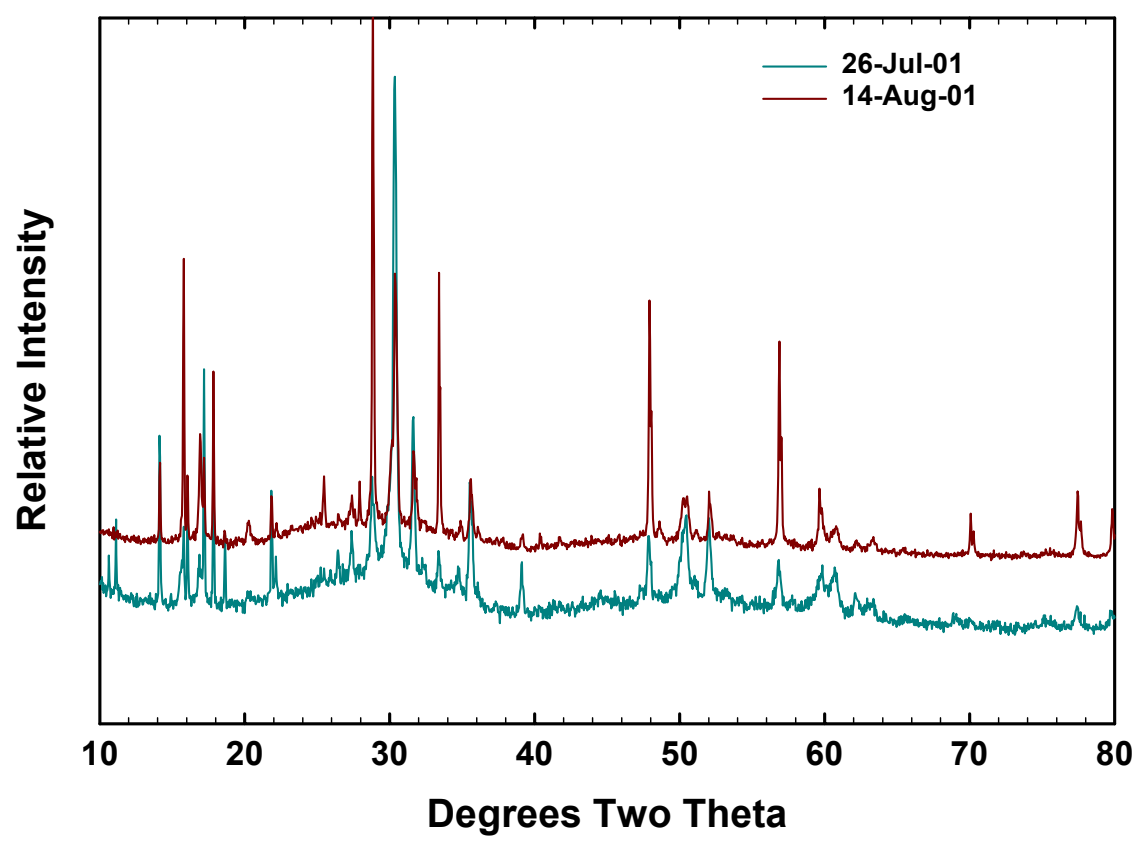

Figure 3.11. Two Recent XRD Patterns Showing the Persistence of the Strong Diffraction Lines Below $20^{\circ}$ Two Theta

In the pyrochlore baseline material, the phases at the start of the study were pyrochlore, zirconolite, and brannerite (Figure 3.14). Within six months, the brannerite peaks disappeared, certainly those at low diffraction angles between 25 and 28 degrees. The peaks from zirconolite and rutile remained strong and sharp, though changes in lattice parameters were evident. By $1 \mathrm{yr}$ (December 2000, third from the bottom in Figure 3.14), the diffraction pattern consisted largely of metamict material, rutile, and residual zirconolite. The most intense peak at about 30 degrees appeared to be a doublet. Without other intense peaks, it is almost impossible to make an assignment to a particular phase, but it is possible that the material had partially transformed to a crystalline fluorite structure. The evidence against fluorite is the peak symmetry. As the peaks broaden, they do so symmetrically. This argues against the ingrowth of a fluorite structure. It is also possible that one of the doublet peaks is due to the (004) reflection after the unit cell has expanded about 5\% along the c-axis. Eight months later (top XRD, July 2001) the residual crystallinity, as shown by the small peak on the larger amorphous peak at about 30 degrees, is largely gone and appears to be from zirconolite.

\subsection{Dissolution Results - Static Tests}

To avoid radiolysis of the water, the MCC-1 tests were limited to 3-d duration. The same specimen was used for each successive test on a given sample. Results from tests on similar materials (Bourcier 1999) suggest that the amount of affected material is on the order of tens of nanometres after a year or two of contact with water in an SPFT. This means that in the 3-d MCC-1 tests performed in this study, the amount of affected material is expected to be very much smaller, and the specimens ought to dissolve during each successive test as if there were a fresh surface. 


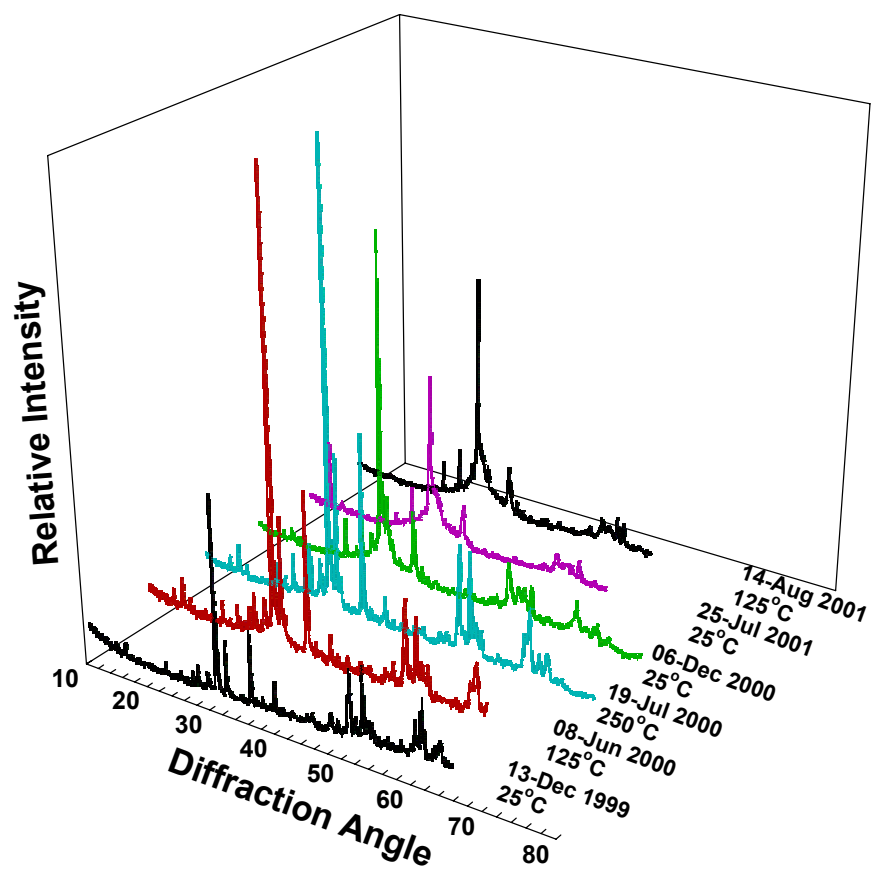

Figure 3.12. Series of XRD Patterns from ${ }^{238} \mathrm{Pu}$-Bearing Zirconolite Showing Effect of Radiation Damage

\subsection{Dissolution Results - Dynamic Tests}

\subsubsection{Experiments with ${ }^{239} \mathrm{Pu}$-Bearing Ceramic}

Experimental conditions, including effluent $\mathrm{pH}$, average flow rate, mass of the specimen, and average net (i.e., background corrected) concentration of the elements are listed in Table 3.1. At $\mathrm{pH}=2$, concentrations of $\mathrm{U}, \mathrm{Pu}, \mathrm{Ti}, \mathrm{Ca}$, and $\mathrm{Gd}$ are well above their respective lower limit of quantification; Mo has been shown to sorb on the surface of precipitated $\mathrm{TiO}_{2}$ (Saripalli et al. 2001). Figure 3.15a illustrates the attainment of steady-state conditions, as evidenced by the constant concentrations of $\mathrm{U}, \mathrm{Gd}$, and $\mathrm{Pu}$ with respect to time after about 250 days. Concentrations of $\mathrm{Mo}, \mathrm{Ti}, \mathrm{Ca}$, and $\mathrm{Hf}$ also reach steady-state values, but at much lower concentrations, and are not shown in Figure 3.15a. Figure 3.15b illustrates and Table 3.2 lists the dissolution rates calculated from the steady-state concentrations of elements given in Table 3.1. Figure 3.15b also illustrates that rates based upon all three elements are the same within experimental uncertainty $\left[\sim 1 \times 10^{-5} \mathrm{~g} /\left(\mathrm{m}^{2} \cdot \mathrm{d}\right)\right]$. 


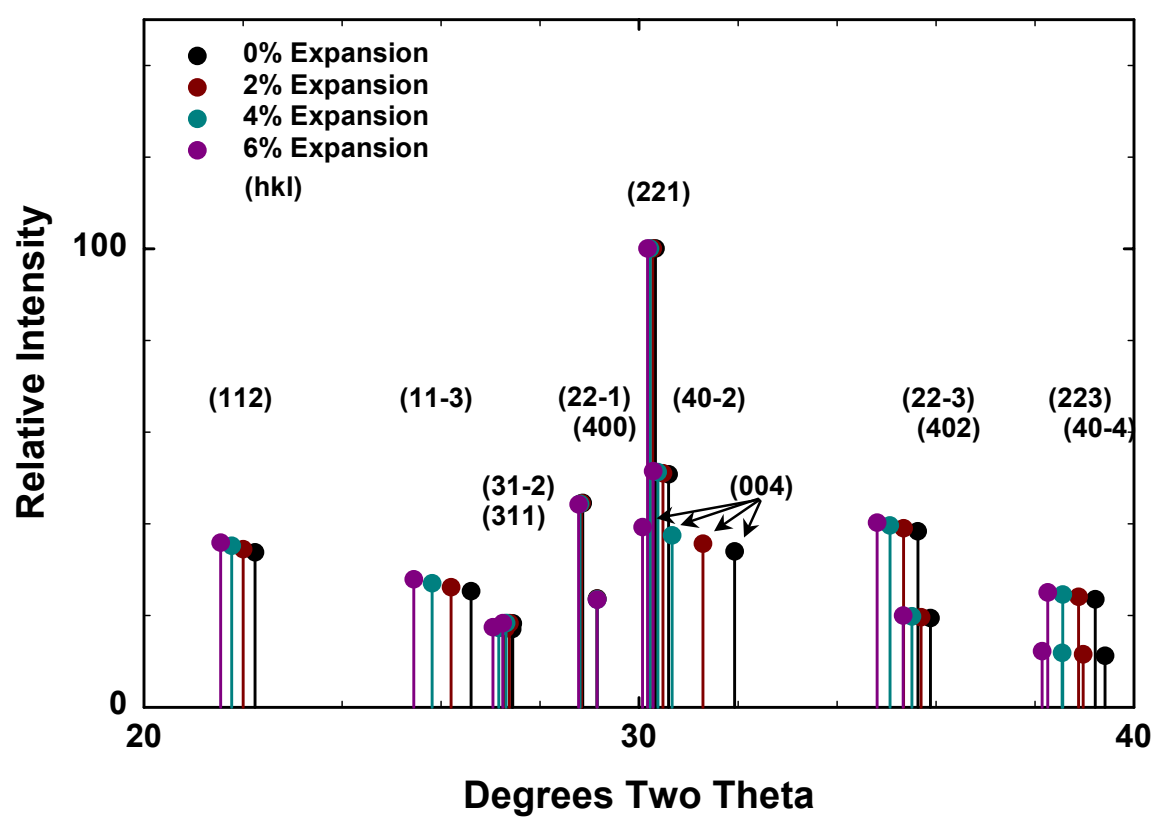

Figure 3.13. Effect of Expansion in c Dimension of Zirconolite Unit Cell on Reflections in Calculated XRD Pattern

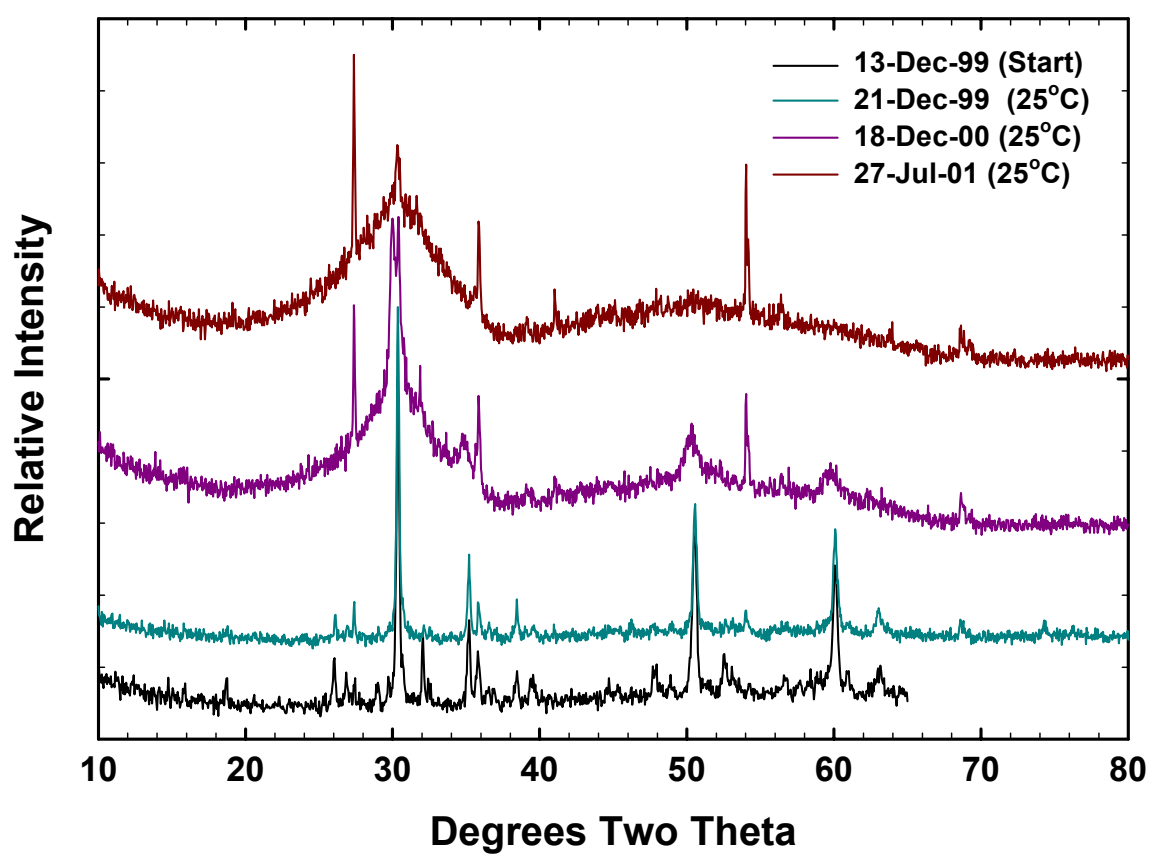

Figure 3.14. Diffraction Patterns Showing Progress of Radiation Damage in ${ }^{238} \mathrm{Pu}$-Bearing Pyrochlore-Baseline Ceramic Specimens Stored at Ambient Temperatures 
These results indicate that the ceramic does not dissolve congruently, or that it dissolves congruently and concentrations of $\mathrm{Ca}$, $\mathrm{Ti}, \mathrm{Mo}$, and $\mathrm{Hf}$ are solubility limited.

Above $\mathrm{pH}=2$, the effluent solutions contain measurable quantities of $\mathrm{Mo}, \mathrm{Ca}$, or U. Accordingly, steady-state dissolution rates can be calculated for the pyrochlore-rich baseline specimen at each $\mathrm{pH}$. In general, concentrations of $\mathrm{Ti}, \mathrm{Hf}$, $\mathrm{Pu}$, and $\mathrm{Gd}$ are at or below their respective detection limits in solution at $\mathrm{pH}>2$. The dependence of the dissolution rate on solution $\mathrm{pH}$ is illustrated in Figure 3.16. Solution $\mathrm{pH}$ values were measured on effluent samples and then adjusted to the in-situ $\mathrm{pH}$ value at $90^{\circ} \mathrm{C}$ with the EQ3NR code (Wolery 1992). Plotted on this diagram are the rates at $\mathrm{pH}=2$, including the rates based on the release of $\mathrm{Ca}, \mathrm{Mo}$, $\mathrm{Gd}, \mathrm{U}$, and $\mathrm{Pu}$. At higher $\mathrm{pH}$ values, the rates based on the release of $\mathrm{Mo}, \mathrm{Ca}$, and $\mathrm{U}$ are plotted. Note that in the case of $\mathrm{Ca}$, the rates near $\mathrm{pH}=8$ are maximum values calculated with the limit of quantification for $\mathrm{Ca}$ of $50 \mathrm{ppb}$ in Equation (1). The data in Figure 3.15 show that rates with respect $\mathrm{Ca}$ and $\mathrm{Mo}$ are greater than the $\mathrm{U}$ rate by a factor of $\sim 10 \mathrm{X}$. Recent reports show that release of Ca to solution is typically faster than rates based on other elements in the specimens (Strachan et al. 2000 and Hart et al. 1999a). Dissolution rates based on Mo release are also faster $(\sim 10 \mathrm{X})$ compared to the $\mathrm{U}$ release rates. The relatively fast release rates of Ca compared to $\mathrm{U}$ may be the result of an ion-exchange process in which Ca diffuses out of the solid to solution, charge-balanced by two counter-diffusing $\mathrm{H}^{+}$. This does not, however, explain the relatively fast Mo rates compared to $\mathrm{U}$. The other possible explanation is that $\mathrm{U}$ is sorbed at the titanate-water interface. The formation of $\mathrm{TiO}_{2}$ polymorphs on the surface of titanate ceramics reacted with aqueous solution has been widely reported in the literature (e.g., Hart et al. 1999b and Strachan et al. 2000). A range of values for the point of zero charge for rutile, a $\mathrm{TiO}_{2}$ polymorph, has been reported in the literature (5.5 to 6.75; see references in James (1972.). Therefore, we would not expect that sorption at $\mathrm{pH}$ values $>7$ would occur because the surface of the sample would have a negative charge, and $U$ is most likely in the form of a negatively charged complex.
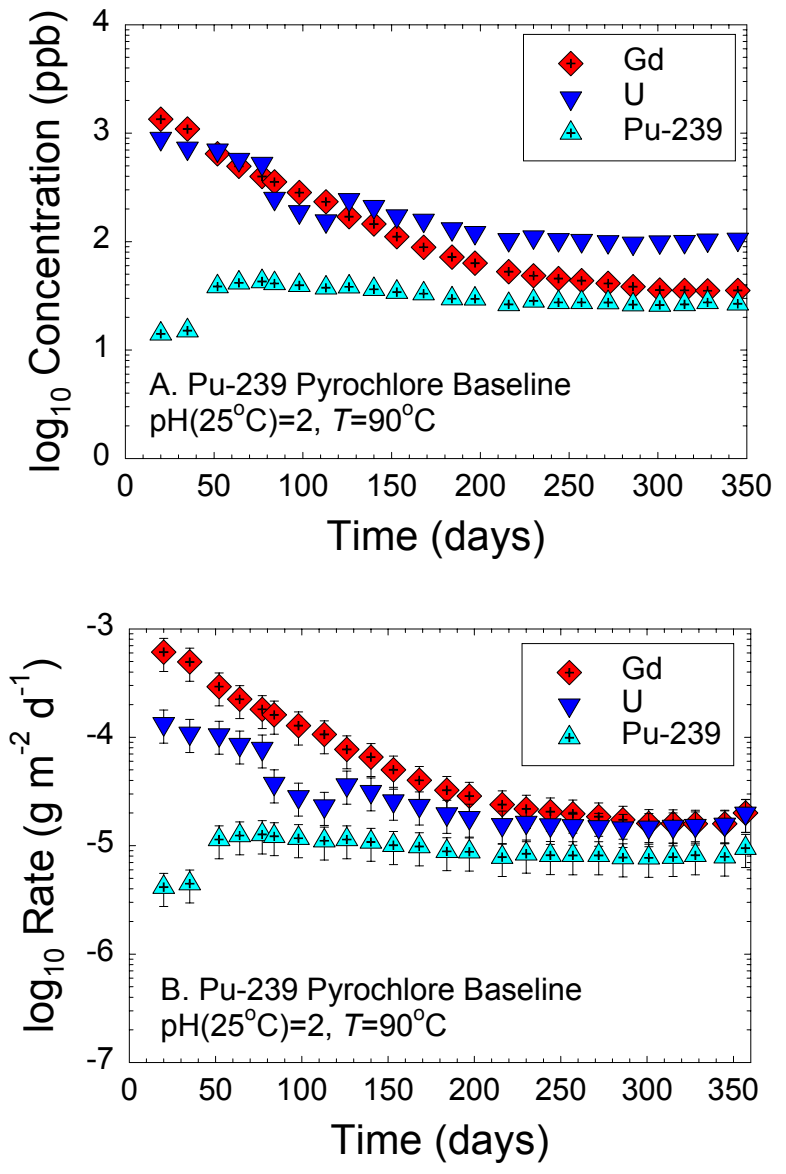

Figure 3.15. Plot of $\log _{10}$ Concentration (A) and $\log _{10}$ Rate (B) Versus Time for Experiments with ${ }^{239} \mathrm{Pu}$ Bearing Pyrochlore Baseline Ceramics at $90^{\circ} \mathrm{C}$, $\mathrm{pH}=2$. Both figures illustrate that steady-state conditions were achieved after $>250$ days. 
Table 3.1. Experimental Conditions and Average Net Concentrations of Elements in Effluent Solutions from SPFT Experiments with ${ }^{238} \mathrm{Pu}-$ and ${ }^{239} \mathrm{Pu}$-Bearing Pyrochlore Baseline (Pbase) Ceramics at $90^{\circ} \mathrm{C}$

\begin{tabular}{|c|c|c|c|c|c|c|c|c|c|}
\hline \multicolumn{10}{|c|}{ Pbase-239 } \\
\hline $\begin{array}{c}\mathrm{pH} \\
\left(25^{\circ} \mathrm{C}\right) \\
\end{array}$ & $\begin{array}{c}\text { mass } \\
(\mathrm{g})\end{array}$ & $\begin{array}{c}\text { average } \\
\text { flow rate } \\
\left(\mathrm{m}^{3} / \mathrm{d}\right)\end{array}$ & $\begin{array}{c}\text { avg. net } \\
\text { conc. Mo } \\
\left(\mathrm{g} / \mathrm{m}^{3}\right)\end{array}$ & $\begin{array}{c}\text { avg. net } \\
\text { conc. Ca } \\
\left(\mathrm{g} / \mathrm{m}^{3}\right)\end{array}$ & $\begin{array}{c}\text { avg. net } \\
\text { conc. Gd } \\
\left(\mathrm{g} / \mathrm{m}^{3}\right)\end{array}$ & $\begin{array}{l}\text { avg. net } \\
\text { conc. Ti } \\
\left(\mathrm{g} / \mathrm{m}^{3}\right) \\
\end{array}$ & $\begin{array}{c}\text { avg. net } \\
\text { conc. Hf } \\
\left(\mathrm{g} / \mathrm{m}^{3}\right)\end{array}$ & $\begin{array}{l}\text { avg. net } \\
\text { conc. U } \\
\left(\mathrm{g} / \mathrm{m}^{3}\right)\end{array}$ & $\begin{array}{c}\text { avg. net } \\
\text { conc. } \mathrm{Pu} \\
\left(\mathrm{g} / \mathrm{m}^{3}\right)\end{array}$ \\
\hline 2.0 & 0.5 & $1.85 \mathrm{E}-06$ & $1.26 \mathrm{E}-03$ & $7.00 \mathrm{E}-02$ & 4.00E-02 & $2.08 \mathrm{E}-02$ & 1.14E-03 & $1.08 \mathrm{E}-01$ & 2.77E-02 \\
\hline 6.8 & 0.5 & $1.85 \mathrm{E}-06$ & $3.92 \mathrm{E}-03$ & 3.13E-01 & $<2.50 E-04$ & $<1.00 E-03$ & $<1.00 E-03$ & $3.41 \mathrm{E}-02$ & $<1.00 E-04$ \\
\hline 8.0 & 0.5 & 1.93E-06 & $1.76 \mathrm{E}-03$ & $7.22 \mathrm{E}-02$ & $<2.50 E-04$ & $<1.00 E-03$ & $<1.00 E-03$ & 1.94E-02 & $<1.00 E-04$ \\
\hline 8.8 & 0.5 & 1.81E-06 & 1.12E-03 & $<5.00 E-02$ & $<2.50 E-04$ & $<1.00 E-03$ & $<1.00 E-03$ & 2.00E-02 & $<1.00 E-04$ \\
\hline 9.1 & 0.5 & 1.92E-06 & 7.79E-04 & $<5.00 E-02$ & $<2.50 E-04$ & $<1.00 E-03$ & $<1.00 E-03$ & 1.67E-02 & $<1.00 E-04$ \\
\hline 11.1 & 0.5 & $1.90 \mathrm{E}-06$ & $<5.00 E-04$ & $7.59 \mathrm{E}-02$ & $<2.50 E-04$ & $<1.00 E-03$ & $<1.00 E-03$ & $4.00 \mathrm{E}-02$ & $<1.00 E-04$ \\
\hline \multicolumn{10}{|c|}{ Pbase-238 } \\
\hline $\begin{array}{c}\mathrm{pH} \\
\left(25^{\circ} \mathrm{C}\right) \\
\end{array}$ & $\begin{array}{c}\text { mass } \\
(\mathrm{g})\end{array}$ & $\begin{array}{c}\text { average } \\
\text { flow rate } \\
\left(\mathrm{m}^{3} / \mathrm{d}\right) \\
\end{array}$ & $\begin{array}{c}\text { avg. net } \\
\text { conc. Mo } \\
\left(\mathrm{g} / \mathrm{m}^{3}\right) \\
\end{array}$ & $\begin{array}{c}\text { avg. net } \\
\text { conc. Ca } \\
\left(\mathrm{g} / \mathrm{m}^{3}\right)\end{array}$ & $\begin{array}{l}\text { avg. net } \\
\text { conc. Gd } \\
\left(\mathrm{g} / \mathrm{m}^{3}\right) \\
\end{array}$ & $\begin{array}{l}\text { avg. net } \\
\text { conc. Ti } \\
\left(\mathrm{g} / \mathrm{m}^{3}\right) \\
\end{array}$ & $\begin{array}{c}\text { avg. net } \\
\text { conc. Hf } \\
\left(\mathrm{g} / \mathrm{m}^{3}\right) \\
\end{array}$ & $\begin{array}{l}\text { avg. net } \\
\text { conc. U } \\
\left(\mathrm{g} / \mathrm{m}^{3}\right) \\
\end{array}$ & $\begin{array}{c}\text { avg. net } \\
\text { conc. } \mathrm{Pu} \\
\left(\mathrm{g} / \mathrm{m}^{3}\right)\end{array}$ \\
\hline 2.0 & 0.25 & $2.07 \mathrm{E}-06$ & $<5.00$ E-03 & N.D. & $2.22 \mathrm{E}-01$ & 1.13E-01 & $2.61 \mathrm{E}+01$ & $2.77 \mathrm{E}+01^{\dagger}$ & $1.79 \mathrm{E}+00^{\S}$ \\
\hline & & & & & & & & $3.79 \mathrm{E}+01^{\ddagger}$ & $1.08 \mathrm{E}+01^{a}$ \\
\hline \multicolumn{10}{|c|}{$\begin{array}{l}\text { Notes: N.D. }=\text { not determined; }{ }^{\dagger 238} \mathrm{U} \text { concentration estimated by mass balance constraints and measurement of }{ }^{239} \mathrm{Pu} \text { by ICP-MS; } \\
\ddagger^{238} \mathrm{U} \text { concentration estimated by mass balance constraints and measurement of }{ }^{238} \mathrm{Pu} \text { measured by GEA; } \\
\S \text { concentration of }{ }^{239} \mathrm{Pu} \text { determined by ICP-MS methods; }{ }^{\circ} \text { concentration of }{ }^{238} \mathrm{Pu} \text { determined by GEA. }\end{array}$} \\
\hline
\end{tabular}


Table 3.2. Steady-State Dissolution Rates and Associated 2- $\sigma$ Uncertainties from SPFT Experiments with ${ }^{238} \mathrm{Pu}$ - and ${ }^{239} \mathrm{Pu}-\mathrm{Bearing}$ Pyrochlore Baseline (Pbase) Ceramics at $90^{\circ} \mathrm{C}$. Also listed are the differences in rates between the two types of ceramics as calculated by the rate ratios of ${ }^{238} \mathrm{Pu} /{ }^{239} \mathrm{Pu}$ ceramics.

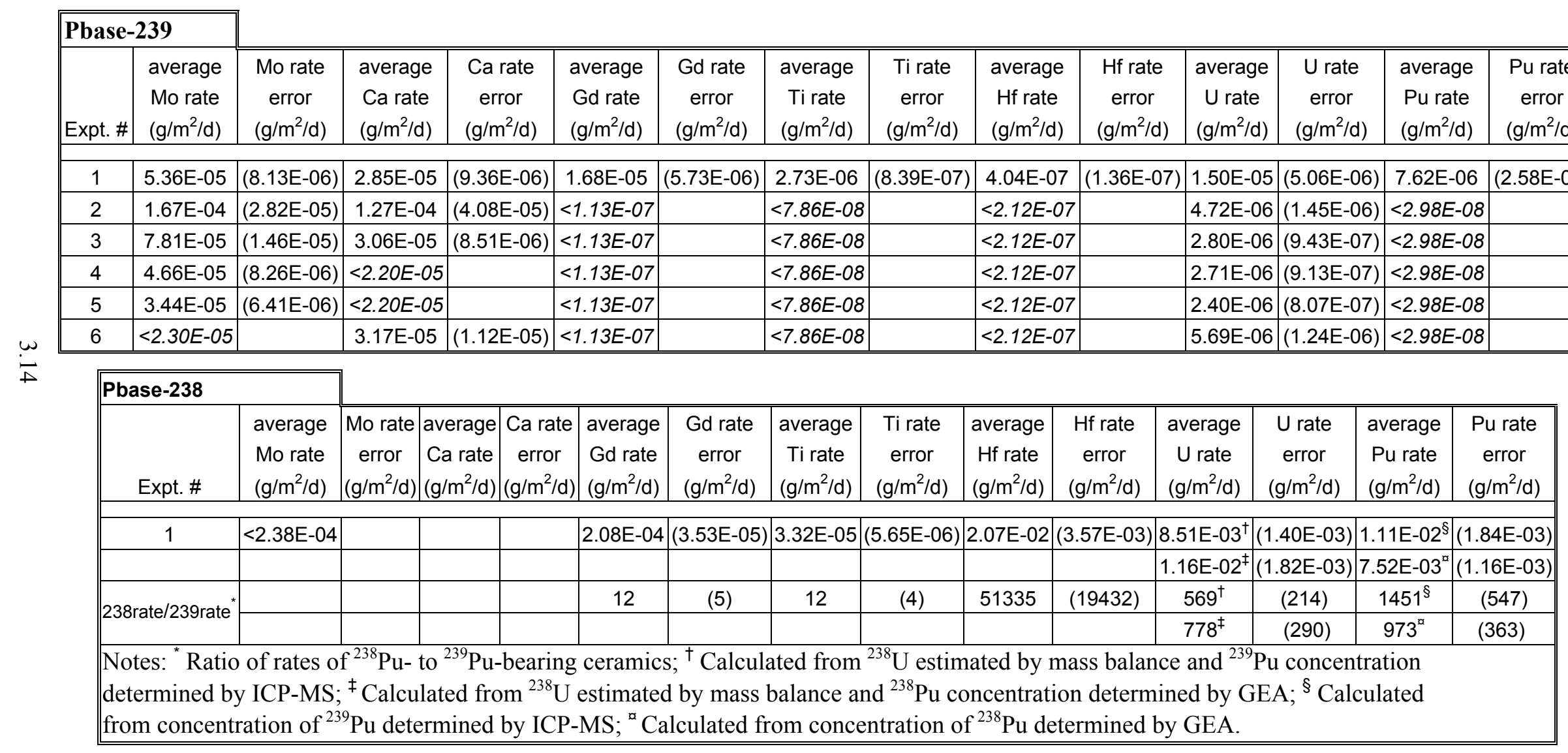


Sorption may, however, explain the behavior of $\mathrm{Mo}$ at $\mathrm{pH}=2$. Saripalli et al. (2001) demonstrated that Mo strongly sorbs to $\mathrm{TiO}_{2}$ polymorphs at low $\mathrm{pH}$ values, indicating a possible mechanism for the apparent retention of Mo at the solid/solution interface. Apparent rates based on $\mathrm{Ca}$ concentrations at $\mathrm{pH}=2$ may be governed by precipitation of a Ca-bearing phase on the surface of the solid specimen.

Dissolution rates based on U clearly display a $\mathrm{pH}$ dependence with faster rates at the acid and basic ends of the $\mathrm{pH}$ range. The rate minimum occurs between $\mathrm{pH}=6.5$ and 8 , forming a broad minimum. Rates based on $\mathrm{Ca}(\mathrm{pH}>5.5)$ also exhibit a minimum over the same $\mathrm{pH}$ range, although they may be faster than the $U$ rates, as discussed above.

In summary, there is no way, a priori, to ascertain whether the rates based upon $\mathrm{U}$ or Mo release yield the "true" dissolution rate for these specimens in solutions above $\mathrm{pH} 2$. There is a general consistency between the release rates of $\mathrm{Ca}$ and Mo over the $\mathrm{pH}$ range studied, but this fact does not prove or disprove which element or

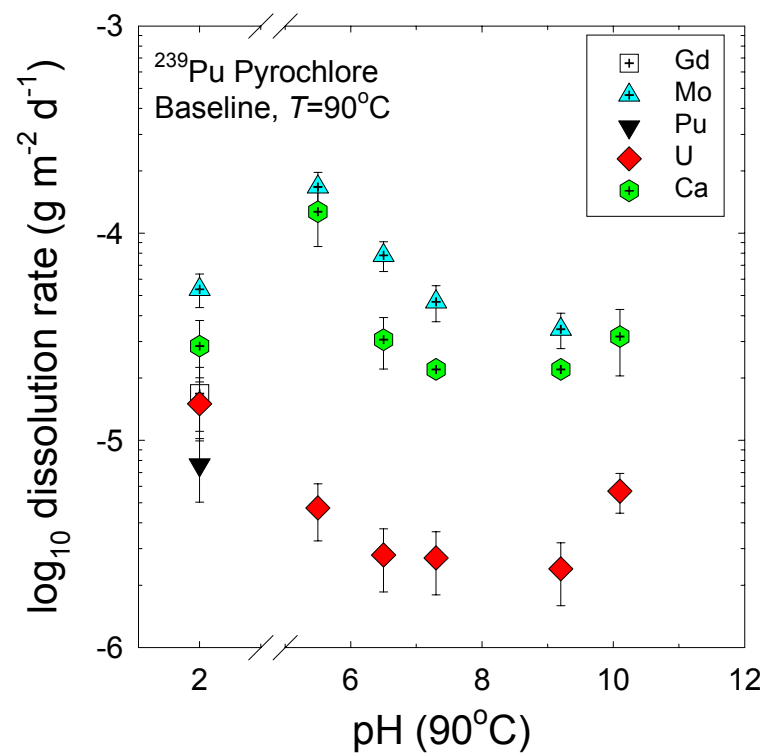

Figure 3.16. Plot of $\log _{10}$ Dissolution Rate Versus Solution $\mathrm{pH}$ for Experiments with ${ }^{239} \mathrm{Pu}$-Bearing Pyrochlore Baseline Ceramics. The data for $\mathrm{U}$ release indicates a small $\mathrm{pH}$ dependence on the rate with a broad minimum between $6.5<\mathrm{pH}<9$. Rates based on Mo and Ca release are faster compared to $\mathrm{U}$, except at $\mathrm{pH}=2$, where sorption of Mo is likely and sorption or precipitation of a Ca phase is likely. elements are the best measures of the dissolution process. At $\mathrm{pH}=2$, however, the apparent rate yielded by release of $\mathrm{Gd}, \mathrm{U}$, and $\mathrm{Ca}$ agree within error and probably represents the "true" dissolution rate. Accordingly, the dissolution rate of the ${ }^{239} \mathrm{Pu}$-bearing specimen in $\mathrm{pH}=2$ solution can be compared to that of the ${ }^{238} \mathrm{Pu}$-bearing specimen at the same experimental conditions. This comparison should provide a useful benchmark for ascertaining the effects of radiation damage on elemental release from pyrochlore-rich ceramics.

\section{6 Experiments with ${ }^{238} \mathrm{Pu}-$ Bearing Materials}

The experiment with the ${ }^{238} \mathrm{Pu}$-bearing pyrochlore baseline composition was conducted exclusively at $\mathrm{pH}=2$ and $90^{\circ} \mathrm{C}$. As in the case of the ${ }^{239} \mathrm{Pu}$-bearing ceramic, the experiment with the ${ }^{238} \mathrm{Pu}$-bearing material ran for nearly 1 yr. Experimental conditions, including $\mathrm{pH}$, flow rate, sample mass, and average steady-state concentrations of elements in the effluent solution, are listed in Table 3.1. Note that the concentration of ${ }^{238} \mathrm{U}$ in solution could not be determined directly with ICP-MS methods because of the presence of ${ }^{238} \mathrm{Pu}$. Therefore, a value of the total concentration of all elements with mass 238 can be determined, and from mass-balance constraints, knowledge of both the ${ }^{238} \mathrm{Pu} /{ }^{239} \mathrm{Pu}$ ratio in the sample, and 
the concentration of ${ }^{239} \mathrm{Pu}$ from mass spectrometry, a value of ${ }^{238} \mathrm{U}$ can be calculated. The technique ${ }^{\text {(a) }}$ of spike recovery is used to give us confidence in the mass 239 value. Alternatively, the concentration of ${ }^{238} \mathrm{U}$ can be calculated from mass-balance considerations and the concentration of ${ }^{238} \mathrm{Pu}$ from GEA. Accordingly, Table 3.1 exhibits the concentration of ${ }^{238} \mathrm{U}$ calculated with both methods. At steady-state conditions, there is a $\sim 25 \%$ difference between the concentrations calculated from the two methods. In the case of $\mathrm{Pu}$, because the sample contains both ${ }^{239} \mathrm{Pu}$ and ${ }^{238} \mathrm{Pu}$, the concentrations of the two isotopes can be determined independently with ICP-MS and GEA techniques, respectively. In general, the concentration of ${ }^{238} \mathrm{Pu}$ calculated from the concentration of ${ }^{239} \mathrm{Pu}$ is greater by $<20 \%$ of that determined directly by GEA techniques. However, over the range of steady-state values, the concentration of ${ }^{238} \mathrm{Pu}$ predicted from the ${ }^{239} \mathrm{Pu}$ assay is approximately $30 \%$ larger. For both $\mathrm{U}$ and $\mathrm{Pu}$, these discrepancies in concentrations translate to rates that are the same within experimental error, as discussed below.

Figure 3.17a illustrates the concentration of elements in effluent solutions with respect to time. As in the case of the experiments with ${ }^{239} \mathrm{Pu}$-bearing ceramics, the concentrations of $\mathrm{Pu}$ and $\mathrm{U}$ appear to reach steady-state levels around 250 days. Concentrations of $\mathrm{Gd}$ and ${ }^{238} \mathrm{Pu}$ increase slowly and then reach a plateau of invariant concentrations with respect to time. Concentrations of both $U$ and Gd increase, reach a maximum, and then decrease to steady state. Although the $\mathrm{Gd}$ concentration is much lower than $\mathrm{U}$, there is a prospect that Gd is not actually at steady-state concentrations; see Figure 3.17a. A third pattern is exhibited by ${ }^{239} \mathrm{Pu}$, which remains more-or-less constant in concentration over the duration of the experiment. Titanium concentrations rise above the quantitation limit after about 210 days. Steady-state rates for the dissolution of ${ }^{238} \mathrm{Pu}$-bearing pyrochlore baseline ceramics are listed in Table 3.2. Rates based on the two methods for calculating the concentration of ${ }^{238} \mathrm{U}$ are tabulated. The ratio of the two ${ }^{238} \mathrm{U}$ rates is $1.3 \mathrm{X}$, which is within experimental uncertainty. Figure $3.17 \mathrm{~b}$ illustrates the calculated dissolution rates with respect to time. Other than $\mathrm{Gd}$ and $\mathrm{Ti}$, the rates based on the elements are equal. The rates based on $\mathrm{Gd}$ and Ti concentrations are 50 to $300 \mathrm{X}$ lower, indicating that release of these two elements is probably solubility limited.

\section{7 Photographic Results}

Recent photographic examination of the specimens suggests no major changes in the visual surfaces. From the geometric density measurements, we know that the dimensions are changing, but this appears to be uniform enough at this time so that there is no observable cracking of the specimen. A higher magnification microscope is being purchased to enhance our ability to document these changes.

(a) The isotopics should have been reported in Strachan et al. (2000), but were not. The average isotopics for the solutions used in the preparation of these specimens is $88.5 \%{ }^{238} \mathrm{Pu}, 10.7 \%{ }^{239} \mathrm{Pu}, 0.71 \%{ }^{240} \mathrm{Pu}, 0.015 \%{ }^{241} \mathrm{Pu}$, and $0.015 \%{ }^{242} \mathrm{Pu}$. The isotopics for each solution are also known. 

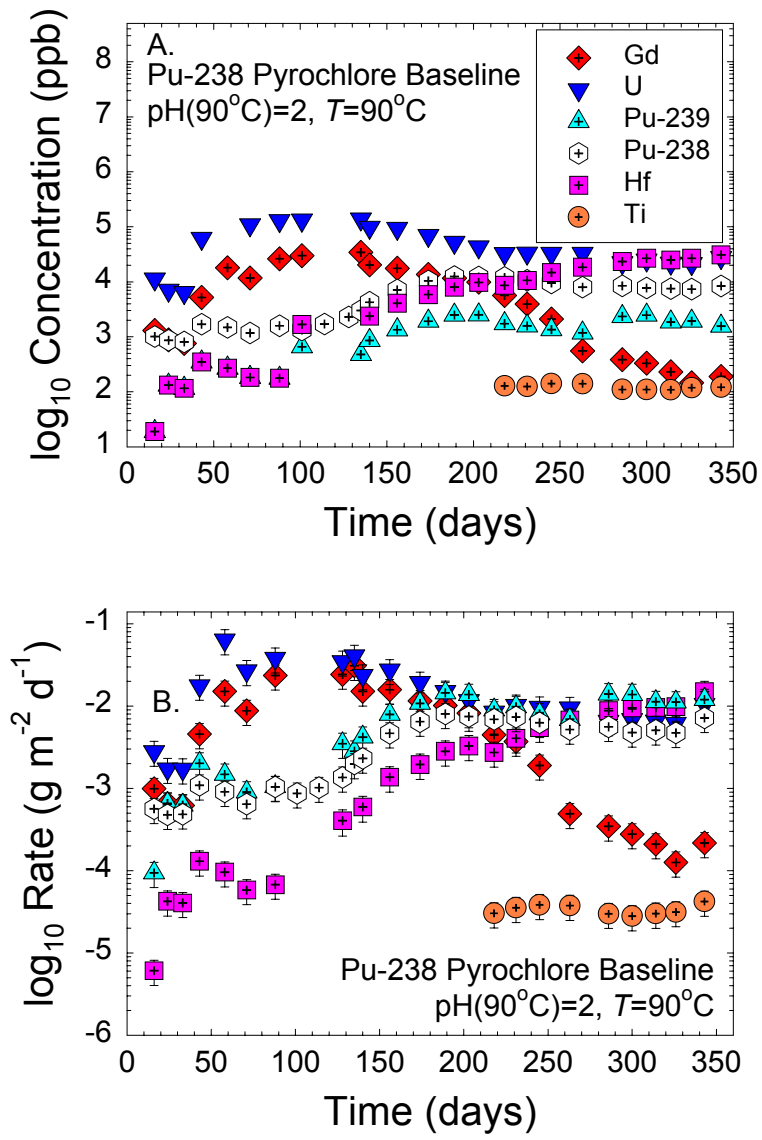

Figure 3.17. Pot $\log _{10}$ Concentration (A) and $\log _{10}$ Rate (B) Versus Time for Experiments with ${ }^{238} \mathrm{Pu}$-Bearing Pyrochlore Baseline Ceramics, $\mathrm{T}=90^{\circ} \mathrm{C}, \mathrm{pH}=2$. 



\section{0 Conclusions}

The results from the density measurements indicate that all specimens in this study are expanding. The volume expansion is from $2 \%$ to approximately $10 \%$. Qualitatively, these results are confirmed with the results from the XRD that indicate the unit cell parameters increased as the phases became metamict. Further analyses are needed to confirm the extent to which the unit cells expanded, but the evidence from the zirconolite-containing specimens suggests expansions of the c-axis greater than 5\%. A rigorous treatment of the XRD to obtain changes in unit cell parameters may not be possible because the expansion occurs with a concomitant broadening of the peaks. Had we obtained more frequent measurements at earlier times, we would have been able to perform these analyses. These measurements have been made by Volkov et al. (2001) and Burakov and Anderson (2001). They found that radiation-damage effects are exhibited in the first several weeks in pyrochlore containing ${ }^{238} \mathrm{Pu}$ at levels similar to those in our samples. Their results show that pyrochlore expands by $1.8 \%$ in approximately 120 days based on the changes in the unit cell dimension (Volkov et al. 2001). The rapid expansion in the pyrochlore ceramic and the rate at which it is rendered amorphous is surprising. From the literature, it was anticipated that pyrochlore and zirconolite would become amorphous at about the same rate (Weber and Matzke 1986 and Weber et al. 1986), although our results indicate that this is highly dependent on composition.

A cursory inspection of Figure 3.15 and Figure 3.17 reveals that release of elements at $\mathrm{pH}=2$ from the ${ }^{238} \mathrm{Pu}$-bearing ceramic relative to the ${ }^{239} \mathrm{Pu}$-bearing ceramic are approximately 1000 times larger for $\mathrm{Pu}$, 700 for $\mathrm{U}$, and 10 for $\mathrm{Gd}$ and $\mathrm{Ti}$ compared to the release of the same elements from the ${ }^{239} \mathrm{Pu}$-bearing ceramic. Release of $\mathrm{Hf}$ from the ${ }^{238} \mathrm{Pu}$-bearing specimen is remarkably fast, especially in light of the relatively low release rate from the ${ }^{239} \mathrm{Pu}$-bearing sample. We are currently unable to provide an adequate explanation for this. Future experiments will aid in determining whether this phenomenon is reproducible. Table 3.2 lists the ratios of the release of element $i$ from the ${ }^{238} \mathrm{Pu}$-bearing ceramic divided by the corresponding release from the ${ }^{239} \mathrm{Pu}$-bearing titanate. The difference in release rates of $\mathrm{Gd}$ and $\mathrm{Ti}$ are $\sim 10 \mathrm{X}$ different, which may reflect a change in solubility of the phases that control release of Gd and Ti to solution. Bakel et al. 1995 argued that, rather than a change in solubility of the solubility limiting solid for $\mathrm{Ti}$, excess titanium in solution likely reflects the relatively slow precipitation rate of $\mathrm{TiO}_{2}$ polymorphs compared to release rates. The difference in rates for $\mathrm{U}$ and $\mathrm{Pu}$ are, by contrast, quite large; approximately 570 to $780 \mathrm{X}$ for $\mathrm{U}$ and 970 to 1450 for $\mathrm{Pu}$. The difference in release rates of $\mathrm{U}$ and $\mathrm{Pu}$ are both larger than their associated uncertainties (Table 3.2). A potential governing factor for the faster release of elements from a pyrochlore matrix is the rate at which the host material becomes metamict. A number of studies Begg et al. (2000) of radiation damage in natural titanate minerals have shown that the host phase becomes metamict after $>1.0 \times 10^{18}$ alpha-events/g or $\sim 1$ dpa (displacements per atom). Balan et al. (2001) argued that metamictization becomes an important factor in the aqueous durability of natural zircon crystals when the amorphized regions become interconnected. They proposed that a dose of $\sim 3.5 \times 10^{18}$ alpha-events/g represents the threshold value between durable and non-durable crystals. On the other hand, a number of recent studies have shown that some solids become metamict faster than previously thought. For example, Begg et al. (2000) found that amorphization of simple synthetic pyrochlore minerals occurs after only $0.18 \mathrm{dpa}$ at room temperature. Buck et al. (1995) reported that

${ }^{239} \mathrm{Pu}$ particles deposited from bomb tests in the 1960s that sorbed onto aluminum oxide grains caused amorphization of the host. They estimated that the dose imparted to the aluminum oxide was on the order of $0.5 \times 10^{-3}$ to $3 \times 10^{-3} \mathrm{dpa}$ or $1 \times 10^{16}$ to $6 \times 10^{16}$ alpha-events/g. Although not a titanate mineral, the aluminum oxide example indicates that a solid can become amorphous at relatively low doses. Studies 
performed by Russian investigators on Pu-bearing pyrochlore samples (12.6 mass $\% \mathrm{PuO}_{2}$ or 9.9 mass $\%$

${ }^{238} \mathrm{PuO}_{2}$ ) show that measurable changes in unit cell parameters and lattice volumes occurs as early as 70 to 84 days after synthesis (Volkov et al. 2001; Burakov and Anderson 2001). This translates to 5 to $40 \times 10^{16}$ alpha-events/g, which is similar to the dose reported by Buck et al. (1995). Strachan et al. (2000) reported the results of 3-day MCC "leach tests" on ${ }^{239} \mathrm{Pu}$ - and ${ }^{238} \mathrm{Pu}$-bearing titanate materials (including some of the same materials used in the SPFT tests). They showed an increase in the normalized release rate of $\mathrm{Pu}$ of nearly $100 \mathrm{X}$ from the ${ }^{238} \mathrm{Pu}$ - compared to the ${ }^{239} \mathrm{Pu}$-bearing materials. They also found that apparent release rates of $\mathrm{Ti}$ were significantly greater from the ${ }^{238} \mathrm{Pu}$ - compared to the ${ }^{239} \mathrm{Pu}$-bearing ceramics.

To quantify the damage suffered by the ${ }^{238} \mathrm{Pu}$-bearing material, a complex set of calculations would be necessary, especially given the multi-component chemistry of the ceramic specimen. Alternatively, we can make a simple calculation of the number of alpha events per mass of sample over the duration of the experiment and compare this value to those cited above. By 200 days after synthesis, the dose imparted to the material is approximately $1 \times 10^{18}$ alpha-events $/ g$. This value is similar to the values given by Ewing and coworkers (Ewing and Headley 1983; Balan et al. 2001) for the dose of amorphization of pyrochlore and zircon, respectively.

What is surprising about these results is that the materials were subjected to the MCC-1 leach test shortly after they were synthesized (less than $\sim 200$ days). In other words, the apparent difference in release rates of $\mathrm{Pu}$, if related to radiation damage of the host, is the result of a small radiation dose. Alternatively, it is possible that the observed difference in release rates is not due to radiation damage, but is due to some other effect or process that we have not identified. 


\subsection{Future Work}

Further analysis of the data is needed to confirm the conclusions that have been made to date. A more thorough treatment of the XRD data will be done to determine the presence or absence of phases and to determine, if possible, the dimensions of the unit cells. These data can then be compared with the "true" and bulk densities. If a sufficient number of these analyses is possible, we will then have a consistent set of data on the expansion of the ceramic materials. A more rigorous comparison of the "true" and bulk densities will provide an indication of the amount of porosity and whether the porosity is changing with increasing radiation damage. This analysis will give an indication of the tendency toward eventual cracking in these ceramics.

There is uncertainty about the effect of radiation damage on the changes to the dissolution rates of these materials. The fact that the ${ }^{238} \mathrm{Pu}$-bearing ceramics show higher dissolution rates than the ${ }^{239} \mathrm{Pu}$ bearing ceramics is not unexpected. However, the fact that we see these effects from the beginning at low amounts of radiation damage is unexpected. Normally, one would expect to see differences between the

${ }^{238} \mathrm{Pu}$ - and ${ }^{239} \mathrm{Pu}$-bearing ceramics to increase with the increasing extent of damage. Several additional tests need to be performed to determine if the effect is due to radiation damage or if the effect is the result of changes to the solution or surface chemistry from the intense radiation field. Extensive experimentation is not warranted or proposed because the higher dissolution rates can be used as bounding values for the long-term dissolution of these ceramics. Some experimentation is warranted because the release rates that we observe already exceed the factor of 30 increase in release that we attributed to radiation-damage effects and that we submitted to the repository database. The factor of 30 included increases from both increased surface area and increased dissolution rate.

Because we were unprepared for the high rate of damage in these ceramics, a representative and limited number of specimens should be annealed to recrystallize the phases. These specimens can then be examined with XRD and gas pycnometry more frequently than we did during the first year to confirm the data from the Russian scientists and to obtain data at earlier times on the other phases in the ceramic phase assemblage. Annealing the specimens to recrystallize the phases takes much less time and effort than preparing fresh specimens. So long as it can be demonstrated (by XRD) that the original crystalline phase assemblage is restored by annealing, this should be an acceptable method to "reset the clock" on these specimens. It will be necessary to check that the original phase assemblage returns after the specimens are annealed. Existing literature suggests that both pyrochlore and zirconolite should recover upon annealing (Weber and Matzke 1986; Weber et al. 1986). Dissolution tests do not need to be performed on these specimens because it is the long-term effects from these tests that are important. Annealing of the specimens should be done after we are sure that the changes in the physical properties have saturated. This is likely to take another year for most materials. These data, the saturation of the changes in the physical properties, and the short-term changes that were missed are important to obtain because they fill the gaps in the data to support the safety case for the repository license. 



\subsection{References}

American Society for Testing and Materials (ASTM). 1998. Standard Test Method for Static Leach

Testing of Monolithic Waste Forms for Disposal of Radioactive Waste, American Society for Testing and Materials.

Bakel, A. J., C. J. Mertz, M. C. Hash, and D. C. Chamberlain. 1995. "The Long-Term Corrosion Behavior of Titanate Ceramics for Pu Disposal: Rate-Controlling Processes." In: The 97th Annual Meeting of the American Ceramic Society, Cincinnati, Ohio, American Ceramic Society.

Balan, E., D. R. Neuville, P. Trocellier, E. Fritsch, J.-P. Muller, and G. Calas. 2001. "Metamictization and Chemical Durability of Detrital Zircon." Amer. Mineral. 86(9): 1025-1033.

Begg, B. D., W. J. Weber, R. Devanathan, J. P. Icenhower, S. Thevuthasan, and B. P. McGrail. 2000. "Heavy-Ion Irradiation Effects in Pyrochlores." Ceram. Trans. 107: 553-560.

Bourcier, W. L. 1999. Interim report on development of a model to predict dissolution behavior of the titanate waste form in a repository and compilation of data from SPFT ceramic dissolution tests (FY99 milestones 4.1e and 4.1f). PIP-00-003 (UCRL-ID-135363), Lawrence Livermore National Laboratory, Livermore, California.

Buck, E. C., N. L. Dietz, J. A. Fortner, J. K. Bates, and N. R. Brown. 1995. "Characterization of Uranium- and Plutonium-Soils by Electron Microscopy." In: Waste Management '95, Tucson, Arizona.

Buck, E. C., N. L. Dietz, J. A. Fortner, J. K. Bates, and N. R. Brown. 1995. "Characterization of Uranium- and Plutonium-Soils by Electron Microscopy.” In: Waste Management '95, Tucson, Arizona.

Burakov, B. E., and E. B. Anderson. 2001. Immobilization of Excess Weapons Plutonium in Russia: A Review of LLNL Contract Work, UCRL-ID-143846, Lawrence Livermore National Laboratory, Livermore, California.

Ebbinghaus, B. B., C. Cicero-Herman, L. Gray, and H. F. Shaw. 1999. Plutonium Immobilization Project: Baseline Formulation, UCRL-ID-133089, Lawrence Livermore National Laboratory, Livermore, California.

Ewing, R. C., and T. J. Headley. 1983. "Alpha-Recoil Damage in Natural Zirconolite (CaZrTi2O7).” J. Nucl. Mater. 119: 102-109.

Hart, K. P., G. R. Lumpkin, Y. Zhang, E. Loi, and S. Leung. 1999a. Durability and natural mineral studies carried out to support development of waste forms for immobilization of plutonium, Australian Nuclear Science and Technology Organisation, Menai, New South Wales, Australia.

Hart, K. P., Y. Zhang, E. Loi, R. A. Day, M. Colella, G. R. Lumpkin, M. W. Stewart, and W. L. Bourcier. 1999b. Durability studies on pyrochlore-rich titanate ceramics designed to immobilize excess Pu.

Materials Research Society, Boston, Massachusetts, Abstract. 
James, R. O., and T.W. Healy. 1972. "Adsorption of Hydrolyzable Metal Ions at the Oxide-Water Interface III. A Thermodynamic Model of Adsorption.” J. Coll. Interfac. Sci. 40(1): 65-81.

McGrail, B. P., W. L. Ebert, A. J. Bakel, and D. K. Peeler. 1997. "Measurement of Kinetic Rate Law Parameters on a Na-Ca-Al Borosilicate Glass for Low-Activity Waste." J. Nucl. Mater. 249: 175-189.

McGrail, B. P., and D. K. Peeler. 1995. Evaluation of the Single-Pass Flow-Through Test to Support a Low-Activity Waste Specification, PNL-10746, Pacific Northwest Laboratory, Richland, Washington.

Meldrum, A., C. W. White, V. Keppens, L. A. Boatner, and R. C. Ewing. 2001. "Irradiation-induced amorphization of $\mathrm{Cd}_{2} \mathrm{Nb}_{2} \mathrm{O}_{7}$ pyrochlore." Phys. Rev. B. 63: 1-11.

Saripalli, K. P., B. P. McGrail, and D. C. Girvin. 2001. "Adsorption of Molybdenum onto Anatase from Dilute Aqueous Solutions." Applied Geochem. In press.

Strachan, D. M., R. D. Scheele, W. C. Buchmiller, J. D. Vienna, R. L. Sell, and R. J. Elovich. 2000. Preparation and Characterization of ${ }^{238}$ Pu-Ceramics for Radiation Damage Experiments, PNNL-13251, Pacific Northwest National Laboratory, Richland, Washington.

TRW Environmental Safety Systems, Inc. (TRW). 1997. Degraded Mode Criticality Analysis of Immobilized Plutonium Waste Forms in a Geologic Repository, A00000000-01717-5705-00014 Rev 01 TRW Environmental Systems, Inc., Las Vegas, Nevada.

Volkov, Y. F., A. N. Lukinykh, S. V. Tomilin, and A. V. Bychkov. 2001. Immobilization of Excess Weapons Plutonium in Russia, UCRL-ID-143846, Livermore National Laboratory. Livermore, California.

Wang, S. X., L. M. Wang, R. C. Ewing, and K. V. Govindan Kutty. 1999a. "Ion Irradiation Effects for Two Pyrochlore Compositions $\mathrm{Gd}_{2} \mathrm{Ti}_{2} \mathrm{O}_{7}$ and $\mathrm{Gd}_{2} \mathrm{Zr}_{2} \mathrm{O}_{7}$." Materials Research Society Symposium Proceedings 540: 355.

Wang, S. X., L. M. Wang, R. C. Ewing, G. S. Was, and G. R. Lumpkin. 1999b. "Ion irradiation-induced phase transformation of pyrochlore and zirconolite." Nuclear Instruments and Methods in Physics Research B. 148: 704-709.

Weber, W. J., R. C. Ewing, C. R. A. Catlow, T. Diaz de la Rubia, L. W. Hobbs, C. Kinoshita, H. Matzke, A. T. Motta, M. Nastasi, E. K. H. Salje, E. R. Vance, and S. J. Zinkle. 1998. "Radiation effects in crystalline ceramics for the immobilization of high-level nuclear waste and plutonium." J. Mater. Res. 13(6): 1434-1484.

Weber, W. J., and H. Matzke. 1986. "Radiation Effects in Actinide Host Phases.” Rad. Effects 98: 9399.

Weber, W. J., J. W. Wald, and H. Matzke. 1985. "Self-Radiation Damage in $\mathrm{Gd}_{2} \mathrm{Ti}_{2} \mathrm{O}_{7}$." Mater. Lett. 3(4): 173-180.

Weber, W. J., J. W. Wald, and H. Matzke. 1986. "Effects of Self-Radiation Damage in Cm-Doped $\mathrm{Gd}_{2} \mathrm{Ti}_{2} \mathrm{O}_{7}$ and $\mathrm{Gd}_{2} \mathrm{Zr}_{2} \mathrm{O}_{7} . "$ J. Nucl. Mater. 138: 196-209. 
Wolery, T. J. 1992. EQ3NR, A Computer Code for Geochemical Aqueous Speciation-Solubility Calculations: Theoretical Manual, Users' Guide and Related Documentation (Version 7.0), UCRL-MA110662 PT III, Lawrence Livermore National Laboratory, Livermore, California. 

Appendix A

\section{Test Matrix}





\section{Appendix A - Test Matrix}

\begin{tabular}{|c|c|c|c|c|c|c|c|c|c|}
\hline \multirow[t]{2}{*}{ Material } & \multicolumn{3}{|c|}{ A(Ambient) } & \multicolumn{3}{|c|}{$B(125 C)$} & \multicolumn{3}{|c|}{$c(250 C)$} \\
\hline & Cyl & Pellets & $\mathrm{TC}$ & Cyl & Pellets & $\mathrm{TC}$ & Cyl & Pellets & $\mathrm{TC}$ \\
\hline 239 Pyrochlore & 1 & 4 & & 1 & 4 & & 1 & 4 & \\
\hline 239 Brannerite & 1 & 4 & & 1 & 4 & & 1 & 4 & \\
\hline 239 Zirconnolite & 1 & 4 & & 1 & 4 & & 1 & 4 & \\
\hline 239 Z-Baseline & 1 & 4 & & 1 & 4 & & 1 & 4 & \\
\hline 239 P-Baseline & 1 & 4 & & 1 & 4 & & 1 & 4 & \\
\hline 239 I-Baseline & 1 & 4 & & 1 & 4 & & 1 & 4 & \\
\hline 239 C-Pyrochlore & 1 & 4 & & 1 & 4 & & 1 & 4 & \\
\hline \multirow[t]{3}{*}{239 C-Zirconolite } & 1 & 4 & & 1 & 4 & & 1 & 4 & \\
\hline & \multicolumn{3}{|c|}{ A(Ambient) } & \multicolumn{3}{|c|}{$B(125 C)$} & \multicolumn{3}{|c|}{$c(250 C)$} \\
\hline & Cyl & Pellets & $\mathrm{TC}$ & Cyl & Pellets & $\mathrm{TC}$ & Cyl & Pellets & $\mathrm{TC}$ \\
\hline 238 Pyrochlore & 2 & 6 & $2^{*}$ & 2 & 6 & 1 & 2 & 6 & 1 \\
\hline 238 Brannerite & 2 & 6 & 1 & 2 & 6 & $2^{*}$ & 2 & 6 & 1 \\
\hline 238 Zirconnolite & 2 & 6 & 1 & 2 & 6 & 1 & 2 & 6 & $2^{*}$ \\
\hline 238 Z-Baseline & 2 & 6 & 1 & 2 & 6 & & 2 & 6 & \\
\hline 238 P-Baseline & 2 & 6 & 1 & 2 & 6 & 1 & 2 & 6 & 1 \\
\hline 238 I-Baseline & 2 & 6 & 1 & & & & 2 & 6 & 1 \\
\hline 238 C-Pyrochlore & 2 & 6 & & & & & & & \\
\hline 238 C-Zirconolite & 2 & 6 & & & & & & & \\
\hline
\end{tabular}

\section{Analysis}

\begin{tabular}{|c|c|c|c|c|c|c|c|c|c|}
\hline & \multicolumn{3}{|c|}{ XRD } & \multicolumn{3}{|c|}{ MCC-1 } & \multicolumn{3}{|c|}{ Density } \\
\hline & Begin & $6 \mathrm{mo}$ & $12 \mathrm{mo}$ & Begin & $6 \mathrm{mo}$ & End & Begin & $6 \mathrm{mo}$ & $12 \mathrm{mo}$ \\
\hline 239 Pyrochlore & $1 \mathrm{~A}, 1 \mathrm{~B}, 1 \mathrm{C}$ & & $1 \mathrm{~A}, 1 \mathrm{~B}, 1 \mathrm{C}$ & $2 \mathrm{~A}, 2 \mathrm{~B}, 2 \mathrm{C}$ & & $2 \mathrm{~A}, 2 \mathrm{~B}, 2 \mathrm{C}$ & $2 \mathrm{~A}, 2 \mathrm{~B}, 2 \mathrm{C}$ & & $2 \mathrm{~A}, 2 \mathrm{~B}, 2 \mathrm{C}$ \\
\hline 239 Brannerite & $1 \mathrm{~A}, 1 \mathrm{~B}, 1 \mathrm{C}$ & & $1 \mathrm{~A}, 1 \mathrm{~B}, 1 \mathrm{C}$ & $2 \mathrm{~A}, 2 \mathrm{~B}, 2 \mathrm{C}$ & & $2 \mathrm{~A}, 2 \mathrm{~B}, 2 \mathrm{C}$ & $2 \mathrm{~A}, 2 \mathrm{~B}, 2 \mathrm{C}$ & & $2 \mathrm{~A}, 2 \mathrm{~B}, 2 \mathrm{C}$ \\
\hline 239 Zirconnolite & $1 \mathrm{~A}, 1 \mathrm{~B}, 1 \mathrm{C}$ & & $1 \mathrm{~A}, 1 \mathrm{~B}, 1 \mathrm{C}$ & $2 \mathrm{~A}, 2 \mathrm{~B}, 2 \mathrm{C}$ & & $2 \mathrm{~A}, 2 \mathrm{~B}, 2 \mathrm{C}$ & $2 \mathrm{~A}, 2 \mathrm{~B}, 2 \mathrm{C}$ & & $2 \mathrm{~A}, 2 \mathrm{~B}, 2 \mathrm{C}$ \\
\hline 239 Z-Baseline & $1 \mathrm{~A}, 1 \mathrm{~B}, 1 \mathrm{C}$ & & $1 \mathrm{~A}, 1 \mathrm{~B}, 1 \mathrm{C}$ & $2 \mathrm{~A}, 2 \mathrm{~B}, 2 \mathrm{C}$ & & $2 \mathrm{~A}, 2 \mathrm{~B}, 2 \mathrm{C}$ & $2 \mathrm{~A}, 2 \mathrm{~B}, 2 \mathrm{C}$ & & $2 \mathrm{~A}, 2 \mathrm{~B}, 2 \mathrm{C}$ \\
\hline 239 P-Baseline & $1 \mathrm{~A}, 1 \mathrm{~B}, 1 \mathrm{C}$ & & $1 \mathrm{~A}, 1 \mathrm{~B}, 1 \mathrm{C}$ & $2 \mathrm{~A}, 2 \mathrm{~B}, 2 \mathrm{C}$ & & $2 \mathrm{~A}, 2 \mathrm{~B}, 2 \mathrm{C}$ & $2 \mathrm{~A}, 2 \mathrm{~B}, 2 \mathrm{C}$ & & $2 \mathrm{~A}, 2 \mathrm{~B}, 2 \mathrm{C}$ \\
\hline 239 I-Baseline & $1 \mathrm{~A}, 1 \mathrm{~B}, 1 \mathrm{C}$ & & $1 \mathrm{~A}, 1 \mathrm{~B}, 1 \mathrm{C}$ & $2 \mathrm{~A}, 2 \mathrm{~B}, 2 \mathrm{C}$ & & $2 \mathrm{~A}, 2 \mathrm{~B}, 2 \mathrm{C}$ & $2 \mathrm{~A}, 2 \mathrm{~B}, 2 \mathrm{C}$ & & $2 \mathrm{~A}, 2 \mathrm{~B}, 2 \mathrm{C}$ \\
\hline 239 C-Pyrochlore & $1 \mathrm{~A}, 1 \mathrm{~B}, 1 \mathrm{C}$ & & $1 \mathrm{~A}, 1 \mathrm{~B}, 1 \mathrm{C}$ & $2 \mathrm{~A}, 2 \mathrm{~B}, 2 \mathrm{C}$ & & $2 \mathrm{~A}, 2 \mathrm{~B}, 2 \mathrm{C}$ & $2 \mathrm{~A}, 2 \mathrm{~B}, 2 \mathrm{C}$ & & $2 \mathrm{~A}, 2 \mathrm{~B}, 2 \mathrm{C}$ \\
\hline \multirow[t]{3}{*}{239 C-Zirconolite } & $1 \mathrm{~A}, 1 \mathrm{~B}, 1 \mathrm{C}$ & & $1 \mathrm{~A}, 1 \mathrm{~B}, 1 \mathrm{C}$ & $2 \mathrm{~A}, 2 \mathrm{~B}, 2 \mathrm{C}$ & & $2 \mathrm{~A}, 2 \mathrm{~B}, 2 \mathrm{C}$ & $2 \mathrm{~A}, 2 \mathrm{~B}, 2 \mathrm{C}$ & & $2 \mathrm{~A}, 2 \mathrm{~B}, 2 \mathrm{C}$ \\
\hline & \multicolumn{3}{|c|}{ XRD } & \multicolumn{3}{|c|}{ MCC-1 } & \multicolumn{3}{|c|}{ Density } \\
\hline & Begin & $6 \mathrm{mo}$ & $12 \mathrm{mo}$ & Begin & $6 \mathrm{mo}$ & $12 \mathrm{mo}$ & Begin & $6 \mathrm{mo}$ & $12 \mathrm{mo}$ \\
\hline 38 Pyrochlore & $1 \mathrm{~A}, 1 \mathrm{~B}, 1 \mathrm{C}$ & $1 \mathrm{~A}, 1 \mathrm{~B}, 1 \mathrm{C}$ & & $2 \mathrm{~A}, 2 \mathrm{~B}, 2 \mathrm{C}$ & $2 \mathrm{~A}, 2 \mathrm{~B}, 2 \mathrm{C}$ & & $2 \mathrm{~A}, 2 \mathrm{~B}, 2 \mathrm{C}$ & $2 \mathrm{~A}, 2 \mathrm{~B}, 2 \mathrm{C}$ & \\
\hline 238 Brannerite & $1 \mathrm{~A}, 1 \mathrm{~B}, 1 \mathrm{C}$ & $1 \mathrm{~A}, 1 \mathrm{~B}, 1 \mathrm{C}$ & & $2 \mathrm{~A}, 2 \mathrm{~B}, 2 \mathrm{C}$ & $2 \mathrm{~A}, 2 \mathrm{~B}, 2 \mathrm{C}$ & & $2 \mathrm{~A}, 2 \mathrm{~B}, 2 \mathrm{C}$ & $2 \mathrm{~A}, 2 \mathrm{~B}, 2 \mathrm{C}$ & \\
\hline 238 Zirconnolite & $1 \mathrm{~A}, 1 \mathrm{~B}, 1 \mathrm{C}$ & $1 \mathrm{~A}, 1 \mathrm{~B}, 1 \mathrm{C}$ & & $2 \mathrm{~A}, 2 \mathrm{~B}, 2 \mathrm{C}$ & $2 \mathrm{~A}, 2 \mathrm{~B}, 2 \mathrm{C}$ & & $2 \mathrm{~A}, 2 \mathrm{~B}, 2 \mathrm{C}$ & $2 \mathrm{~A}, 2 \mathrm{~B}, 2 \mathrm{C}$ & \\
\hline 238 Z-Baseline & $1 \mathrm{~A}, 1 \mathrm{~B}, 1 \mathrm{C}$ & & $1 \mathrm{~A}, 1 \mathrm{~B}, 1 \mathrm{C}$ & $2 \mathrm{~A}, 2 \mathrm{~B}, 2 \mathrm{C}$ & & $2 \mathrm{~A}, 2 \mathrm{~B}, 2 \mathrm{C}$ & $2 \mathrm{~A}, 2 \mathrm{~B}, 2 \mathrm{C}$ & $2 \mathrm{~A}, 2 \mathrm{~B}, 2 \mathrm{C}$ & \\
\hline 238 P-Baseline & $1 \mathrm{~A}, 1 \mathrm{~B}, 1 \mathrm{C}$ & & $1 \mathrm{~A}, 1 \mathrm{~B}, 1 \mathrm{C}$ & $2 \mathrm{~A}, 2 \mathrm{~B}, 2 \mathrm{C}$ & & $2 \mathrm{~A}, 2 \mathrm{~B}, 2 \mathrm{C}$ & $2 \mathrm{~A}, 2 \mathrm{~B}, 2 \mathrm{C}$ & $2 \mathrm{~A}, 2 \mathrm{~B}, 2 \mathrm{C}$ & \\
\hline 238 I-Baseline & $1 \mathrm{~A}, 1 \mathrm{~B}, 1 \mathrm{C}$ & & $1 \mathrm{~A}, 1 \mathrm{~B}, 1 \mathrm{C}$ & $2 \mathrm{~A}, 2 \mathrm{~B}, 2 \mathrm{C}$ & & $2 \mathrm{~A}, 2 \mathrm{~B}, 2 \mathrm{C}$ & $2 \mathrm{~A}, 2 \mathrm{~B}, 2 \mathrm{C}$ & $2 \mathrm{~A}, 2 \mathrm{~B}, 2 \mathrm{C}$ & \\
\hline 238 C-Pyrochlore & $1 \mathrm{~A}, 1 \mathrm{~B}, 1 \mathrm{C}$ & & $1 \mathrm{~A}, 1 \mathrm{~B}, 1 \mathrm{C}$ & $2 \mathrm{~A}, 2 \mathrm{~B}, 2 \mathrm{C}$ & & $2 \mathrm{~A}, 2 \mathrm{~B}, 2 \mathrm{C}$ & $2 \mathrm{~A}, 2 \mathrm{~B}, 2 \mathrm{C}$ & & $2 \mathrm{~A}, 2 \mathrm{~B}, 2 \mathrm{C}$ \\
\hline 238 C-Zirconolite & $1 \mathrm{~A}, 1 \mathrm{~B}, 1 \mathrm{C}$ & & $1 \mathrm{~A}, 1 \mathrm{~B}, 1 \mathrm{C}$ & $2 \mathrm{~A}, 2 \mathrm{~B}, 2 \mathrm{C}$ & & $2 \mathrm{~A}, 2 \mathrm{~B}, 2 \mathrm{C}$ & $2 \mathrm{~A}, 2 \mathrm{~B}, 2 \mathrm{C}$ & & $2 \mathrm{~A}, 2 \mathrm{~B}, 2 \mathrm{C}$ \\
\hline
\end{tabular}

$\mathrm{A}=$ Ambient storage temperature

$\mathrm{B}=125 \mathrm{C}$ storage temperature

$\mathrm{C}=250 \mathrm{C}$ storage temperature

cyl = sample containers storage cylinders.

tc $=$ storage cylinders with thermocouples inserted in the base; those with a "2" have one near the sample on the inside.

Sample names: Z-baseline (zirconolite-rich); P-Baseline (pyrochlore-rich); I-Baseline (impurity-containing); C-Pyrochlore (coarse grained).

Analysis times: every 6 months; every 12 months.

Density: bulk and gas pycnometer measurements. 

Appendix B

\section{Test Sample Composition}





\section{Appendix B - Test Sample Composition}

Table B.1. Compositions of the Test Materials

\begin{tabular}{|c|c|c|c|c|c|c|}
\hline \multirow[b]{2}{*}{ Component } & \multicolumn{2}{|c|}{${ }^{238} \mathrm{Pu}$-Pyrochlore } & \multicolumn{2}{|c|}{${ }^{238} \mathrm{Pu}$-Pyrochlore } & \multicolumn{2}{|c|}{$\begin{array}{c}{ }^{238} \text { Pu-Pyrochlore } \\
\text { Baseline }\end{array}$} \\
\hline & $\operatorname{mass} \%$ & mol \% & $\operatorname{mass} \%$ & mol \% & $\operatorname{mass} \%$ & mol \% \\
\hline $\mathrm{Al}_{2} \mathrm{O}_{3}$ & 0.00 & 0.00 & 0.00 & 0.00 & 0.00 & 0.00 \\
\hline $\mathrm{CaO}$ & 12.06 & 24.89 & 12.53 & 25.05 & 9.91 & 21.13 \\
\hline $\mathrm{Gd}_{2} \mathrm{O}_{3}$ & 7.65 & 2.44 & 7.96 & 2.46 & 7.95 & 2.62 \\
\hline $\mathrm{HfO}_{2}$ & 10.88 & 5.98 & 11.30 & 6.02 & 9.61 & 5.46 \\
\hline $\mathrm{TiO}_{2}$ & 36.17 & 52.39 & 37.58 & 52.72 & 36.70 & 54.89 \\
\hline $\mathrm{PuO}_{2}$ & 12.31 & 5.27 & 11.27 & 4.68 & 11.84 & 5.24 \\
\hline $\mathrm{UO}_{2}$ & 20.82 & 8.93 & 19.24 & 8.98 & 23.88 & 10.57 \\
\hline $\mathrm{MoO}_{3}$ & 0.10 & 0.09 & 0.12 & 0.09 & 0.11 & 0.10 \\
\hline \multirow[b]{2}{*}{ Component } & \multicolumn{2}{|c|}{$\begin{array}{l}{ }^{238} \mathrm{Pu} \text {-Impure } \\
\text { Baseline }\end{array}$} & \multicolumn{2}{|c|}{${ }^{238} \mathrm{Pu}$-Zirconolite } & \multicolumn{2}{|c|}{$\begin{array}{c}{ }^{238} \mathrm{Pu} \text {-Zirconolite } \\
\text { Baseline }\end{array}$} \\
\hline & $\operatorname{mass} \%$ & mol\% & $\operatorname{mass} \%$ & mol\% & $\operatorname{mass} \%$ & mol\% \\
\hline $\mathrm{Al}_{2} \mathrm{O}_{3}$ & 0.50 & 0.58 & 1.74 & 1.97 & 1.74 & 1.97 \\
\hline $\mathrm{CaO}$ & 9.44 & 19.95 & 10.20 & 21.03 & 10.20 & 21.03 \\
\hline $\mathrm{Gd}_{2} \mathrm{O}_{3}$ & 7.54 & 2.47 & 2.06 & 0.66 & 2.06 & 0.66 \\
\hline $\mathrm{HfO}_{2}$ & 10.07 & 5.67 & 43.08 & 23.66 & 43.08 & 23.66 \\
\hline $\mathrm{TiO}_{2}$ & 34.03 & 50.51 & 33.61 & 48.63 & 33.61 & 48.63 \\
\hline $\mathrm{PuO}_{2}$ & 11.26 & 4.94 & 7.40 & 3.17 & 7.40 & 3.17 \\
\hline $\mathrm{UO}_{2}$ & 22.57 & 9.91 & 1.81 & 0.79 & 1.81 & 0.79 \\
\hline $\mathrm{MoO}_{3}$ & 0.28 & 0.26 & 0.10 & 0.09 & 0.10 & 0.09 \\
\hline Impurities & 4.33 & 5.71 & & & & \\
\hline
\end{tabular}


Table B.2. Composition of the Impurities Used in the Test Materials

\begin{tabular}{|c|c|c|c|c|c|c|}
\hline \multirow[b]{2}{*}{ Component } & \multicolumn{2}{|c|}{${ }^{239}$ Pu-Pyrochlore } & \multicolumn{2}{|c|}{$\begin{array}{c}{ }^{239} \mathrm{Pu} \text {-Pyrochlore } \\
\text { Baseline }\end{array}$} & \multicolumn{2}{|c|}{$\begin{array}{l}{ }^{239} \text { Pu-Impure } \\
\text { Baseline }\end{array}$} \\
\hline & $\operatorname{mass} \%$ & mol \% & $\operatorname{mass} \%$ & mol \% & $\operatorname{mass} \%$ & $\mathrm{~mol} \%$ \\
\hline $\mathrm{Al}_{2} \mathrm{O}_{3}$ & 0.00 & 0.00 & 0.00 & 0.00 & 0.50 & 0.58 \\
\hline $\mathrm{CaO}$ & 12.07 & 24.91 & 9.94 & 21.15 & 9.20 & 19.47 \\
\hline $\mathrm{Gd}_{2} \mathrm{O}_{3}$ & 7.64 & 2.44 & 7.94 & 2.61 & 7.62 & 2.49 \\
\hline $\mathrm{HfO}_{2}$ & 10.88 & 5.98 & 9.63 & 5.46 & 10.21 & 5.76 \\
\hline $\mathrm{TiO}_{2}$ & 36.15 & 52.38 & 36.82 & 54.99 & 34.38 & 51.06 \\
\hline $\mathrm{PuO}_{2}$ & 12.35 & 5.27 & 11.88 & 5.23 & 10.83 & 4.74 \\
\hline $\mathrm{UO}_{2}$ & 20.82 & 8.92 & 23.67 & 10.46 & 22.70 & 9.98 \\
\hline $\mathrm{MoO}_{2}$ & 0.10 & 0.09 & 0.10 & 0.10 & 0.27 & 0.25 \\
\hline Impurities & & & & & 4.30 & 5.66 \\
\hline \multirow[b]{2}{*}{ Component } & \multicolumn{2}{|c|}{${ }^{239} \mathrm{Pu}$-Zirconolite } & \multicolumn{2}{|c|}{$\begin{array}{c}{ }^{239} \mathrm{Pu} \text {-Zirconolite } \\
\text { Baseline }\end{array}$} & & \\
\hline & $\operatorname{mass} \%$ & mol\% & $\operatorname{mass} \%$ & mol\% & & \\
\hline $\mathrm{Al}_{2} \mathrm{O}_{3}$ & 1.88 & 2.13 & 1.13 & 1.35 & & \\
\hline $\mathrm{CaO}$ & 10.18 & 20.99 & 9.22 & 19.94 & & \\
\hline $\mathrm{Gd}_{2} \mathrm{O}_{3}$ & 2.06 & 0.66 & 6.60 & 2.21 & & \\
\hline $\mathrm{HfO}_{2}$ & 43.01 & 23.63 & 24.18 & 13.92 & & \\
\hline $\mathrm{TiO}_{2}$ & 33.56 & 48.57 & 33.82 & 51.31 & & \\
\hline $\mathrm{PuO}_{2}$ & 7.39 & 3.15 & 9.56 & 4.28 & & \\
\hline $\mathrm{UO}_{2}$ & 1.83 & 0.79 & 15.38 & 6.90 & & \\
\hline $\mathrm{MoO}_{2}$ & 0.10 & 0.09 & 0.10 & 0.09 & & \\
\hline
\end{tabular}




\section{Appendix C}

\section{Specimen Geometric Densities}





\section{Appendix C - Specimen Geometric Densities}

Geometric Denisty of ${ }^{238} \mathrm{Pu}$-Bearing Specimens, $10^{3} \mathrm{~kg} / \mathrm{m}^{3}$

\begin{tabular}{|c|c|c|c|c|c|c|c|c|c|c|c|c|}
\hline Temperature, ${ }^{\circ} \mathrm{C}$ & \multicolumn{2}{|c|}{ Pyrochlore } & \multicolumn{2}{|c|}{ Zirconolite } & \multicolumn{2}{|c|}{ P Baseline } & \multicolumn{2}{|c|}{ IBaseline } & \multicolumn{2}{|c|}{ Z Baseline } & \multirow{2}{*}{$\begin{array}{c}\text { C Pyrochlore } \\
25\end{array}$} & \multirow{2}{*}{$\begin{array}{c}\text { C Zirconolite } \\
25\end{array}$} \\
\hline Time, $d$ & 25 & 125 & 25 & 125 & 25 & 125 & 25 & 125 & 25 & 125 & & \\
\hline 94 & $6.01(1)$ & & & & & & & & & & & \\
\hline 96 & & & $5.36(1)$ & & $4.76(1)$ & & & & & & & \\
\hline 258 & & & & $5.09(44)$ & & & & & & & & \\
\hline 259 & & $5.21(35)$ & & & & $4.45(29)$ & & $5.11(38)$ & & $6.09(49)$ & & \\
\hline 413 & & & & & & & & & $6.08(7)$ & & & \\
\hline 416 & & & & & $4.52(6)$ & & $5.02(5)$ & & & & $4.90(5)$ & $5.16(9)$ \\
\hline 424 & $5.16(4)$ & & $4.86(13)$ & & & & & & & & & \\
\hline 656 & & & & & & & $4.77(3)$ & & & & $4.42(5)$ & $4.89(9)$ \\
\hline 657 & $5.11(5)$ & $5.01(5)$ & $4.56(9)$ & & $4.33(5)$ & & & & $5.80(7)$ & & & \\
\hline 675 & $5.08(6)$ & $4.99(5)$ & & & & $4.23(5)$ & & & & & & \\
\hline 676 & $5.09(4)$ & $5.09(4)$ & & $4.82(10)$ & & $4.37(5)$ & & $4.88(3)$ & & $5.84(6)$ & & \\
\hline
\end{tabular}


PNNL-13721

\section{Distribution}

No. of

\section{Copies}

\section{OFFSITE}

L. Jardine

Lawrence Livermore National Laboratory

P.O. Box 808, L-195

Livermore, California 94551

Dr. Werner Lutze

University of New Mexico

209 Farris Engineering Building

Albuquerque, New Mexico 87131

Dr. Rodney Ewing

University of Michigan

Geological Sciences

1006 C C Little

Ann Arbor Michigan 48109-1063

L. A. Boatner

Oak Ridge National Laboratory

PO Box 2008

Oak Ridge, Tennessee 37831-6056

S. G. Johnson

Argonne National Laboratory

P.O. Box 2528

Idaho Falls, Idaho 83403-2528
No. of

Copies

\section{FOREIGN}

B. Grambow

Ecole de Mines de Nantes

Laboratoire SUBATECH

4 Rue Alfred Kastler

F 44307 Nantes Cedex 3.

FRANCE

\section{A. Jostsons}

Australian Nuclear Science and

Technology Organization

New Illawarra Road

Lucas Heights

NSW 2234

AUSTRALIA

E. R. Vance

Australian Nuclear Science and Technology Organization

New Illawarra Road

Lucas Heights

NSW 2234

AUSTRALIA

G. R. Lumpkin

Australian Nuclear Science and Technology Organization

New Illawarra Road

Lucas Heights

NSW 2234

AUSTRALIA

L. Nachmilner

Nuclear Research Institute

CZ 25068 Řež

CZECH REPUBLIC

Distr. 1 
No. of

Copies

FOREIGN

K. Spahiu

SKB

Box 5864

10240 Stockholm

SWEDEN

ONSITE

2 DOE Richland Operations Office

D. L Biancosino
No. of

Copies

\section{ONSITE}

\section{Pacific Northwest National Laboratory}

B. O. Barnes

P8-50

W. C. Buchmiller

K6-24

R. J. Elovich

P7-25

BD Hanson

P7-25

J. P. Icenhower

K6-81

D. E. Knutson

P7-25

B. P. McGrail

K6-81

L. M. Peurrung

P8-20

H. T. Schaef/MJ O'Hara

K6-81

R. D. Scheele (5)

P7-25

R. L. Sell

P7-25

D. M. Strachan (10)

K6-24

J. D. Vienna

K6-24

W. J. Weber

K8-93

Information Release Office (2)

K1-06 